\title{
Thermochemical Characterization of Eight Seaweed Species and Evaluation of Their Potential Use as an Alternative for Biofuel Production and Source of Bioactive Compounds
}

\author{
Lucía Cassani $^{1,2} \mathbb{D}$, Catarina Lourenço-Lopes ${ }^{1} \mathbb{D}$, Marta Barral-Martinez $^{1} \mathbb{D}$, Franklin Chamorro ${ }^{1} \mathbb{D}$, \\ Pascual Garcia-Perez ${ }^{1,3}(\mathbb{D})$, Jesus Simal-Gandara ${ }^{1, *(\mathbb{D})}$ and Miguel A. Prieto $1,4, * \mathbb{D}$
}

Citation: Cassani, L.; Lourenço-Lopes, C.; Barral-Martinez, M.; Chamorro, F.; Garcia-Perez, P.; Simal-Gandara, J.; Prieto, M.A. Thermochemical Characterization of Eight Seaweed Species and Evaluation of Their Potential Use as an Alternative for Biofuel Production and Source of Bioactive Compounds. Int. J. Mol. Sci. 2022, 23, 2355. https://doi.org/ $10.3390 /$ ijms23042355

Academic Editor: Diego A. Moreno

Received: 31 December 2021

Accepted: 15 February 2022

Published: 21 February 2022

Publisher's Note: MDPI stays neutral with regard to jurisdictional claims in published maps and institutional affiliations.

Copyright: (C) 2022 by the authors. Licensee MDPI, Basel, Switzerland. This article is an open access article distributed under the terms and conditions of the Creative Commons Attribution (CC BY) license (https:// creativecommons.org/licenses/by/ $4.0 /)$
1 Nutrition and Bromatology Group, Department of Analytical and Food Chemistry, Faculty of Food Science and Technology, Universidade de Vigo, Ourense Campus, E32004 Ourense, Spain; luciavictoria.cassani@uvigo.es (L.C.); c.lopes@uvigo.es (C.L.-L.); marta.barral@uvigo.es (M.B.-M.); franklin.noel.chamorro@uvigo.es (F.C.); pasgarcia@uvigo.es (P.G.-P.)

2 Instituto de Investigaciones en Ciencia y Tecnología de Materiales (INTEMA, CCT-CONICET), Av. Colón 10850, Mar del Plata 7600, Argentina

3 Department for Sustainable Food Process, Università Cattolica del Sacro Cuore, Via Emilia Parmense 84, 29122 Piacenza, Italy

4 Centro de Investigação de Montanha (CIMO), Instituto Politécnico de Bragança, Campus de Santa Apolonia, 5300-253 Bragança, Portugal

* Correspondence: jsimal@uvigo.es (J.S.-G.); mprieto@uvigo.es (M.A.P.)

\begin{abstract}
Algae are underexplored resources in Western countries and novel approaches are needed to boost their industrial exploitation. In this work, eight edible seaweeds were subjected to their valorization in terms of nutritional characterization, thermochemical properties, and bioactive profile. Our results suggest that seaweeds present a rich nutritional profile, in which carbohydrates are present in high proportions, followed by a moderate protein composition and a valuable content of $\omega-3$ polyunsaturated fatty acids. The thermochemical characterization of seaweeds showed that some macroalgae present a low ash content and high volatile matter and carbon fixation rates, being promising sources for alternative biofuel production. The bioactive profile of seaweeds was obtained from their phenolic and carotenoid content, together with the evaluation of their associated bioactivities. Among all the species analyzed, Porphyra purpurea presented a balanced composition in terms of carbohydrates and proteins and the best thermochemical profile. This species also showed moderate anti-inflammatory activity. Additionally, Himanthalia elongata extracts showed the highest contents of total phenolics and a moderate carotenoid content, which led to the highest rates of antioxidant activity. Overall, these results suggest that seaweeds can be used as food or functional ingredient to increase the nutritional quality of food formulations.
\end{abstract}

Keywords: macroalgae; nutritional composition; alternative bioenergy resource; functional ingredients; antioxidant activity; anti-inflammatory activity

\section{Introduction}

Algae have traditionally been used as sea vegetables, animal feed, fertilizers, and exploited by the phycocolloids industry for the extraction of agar-agar, carrageenan, and alginate [1]. In spite of being a billionaire industry with a market size valued at USD 6 billion per year, with China, Japan, and South Korea being the main consumers [2], the worldwide algae production is still restricted to the cultivation of edible species and for the phycocolloids industry [3]. The most widely consumed species belong to the Undaria (wakame) (Ochrophyta, Phaeophyceae), Porphyra (nori) (Rhodophyta), and Laminaria (kombu) (Ochrophyta, Phaeophyceae) genera [4]. Within the green seaweed phylum, Ulva rigida (sea lettuce) is also used for human consumption [5]. Other works have highlighted the valuable nutritional composition of different seaweed classes (green, brown, and red) 
as fresh or dried vegetables, even suggesting their incorporation as ingredients in several processed foods. From a nutritional point of view, seaweeds are attractive for their high protein content (up to $47 \%$ of dry weight in red species), being comparable to meat and dry legumes. Their low-fat content is also remarkable with a healthy ratio of fatty acids $\omega 6 / \omega 3$, and high dietary fiber content, which can reach $50 \%$ of dry weight in brown species with soluble fiber as the predominant fraction [6]. From a technological perspective, seaweeds present many functional properties, such as water retention capacity, oil holding capacity, swelling, etc, associated with their protein and dietary fiber content that supported their incorporation into farinaceous products (bread, noodles, pasta, cake, biscuit, cookies, etc. [6]).

In addition, seaweeds are an important and underexploited source of bioactive compounds, including sulfated polysaccharides (fucoidan), polyphenols (phlorotannins), and natural pigments (fucoxanthin, $\beta$-carotene, chlorophylls, xanthophylls), among others [7-9]. These compounds have proved to have biological activities, acting as antioxidant, antimicrobial, anti-inflammatory, anti-tumoral, antifungal, antiviral, and neuroprotective agents, and thus, can be used as functional ingredients in many innovative and technological applications in food, cosmeceutical, and pharmaceutical industries [8,9].

On the other hand, seaweeds have been gaining attention as an alternative renewable source for "third-generation" biofuels production. Seaweed biomass is an attractive feedstock since it has many advantages over terrestrial plant biomass including higher growth rate, higher rate of carbon dioxide fixation by photosynthesis, absence of hemicellulose and lignin, which facilitates the thermal depolymerization, no requirements of arable land for cultivation, and the ability to grow in saltwater or wastewater [10]. Therefore, this offers new opportunities to exploit these promising natural resources for biofuel production either from wastes generated after phycocolloids and food production or raw biomass [11].

Anaerobic digestion, fermentation, transesterification, liquefaction, and thermochemical conversion can convert seaweed biomass into valuable energy products, for instance, biogas, bioethanol, bio-methane, biodiesel, and bio-oils [12]. Among different pathways, thermochemical conversion is one of the most extensively studied processes in recent years since different biofuel products in solid, liquid, and gaseous states can be generated from seaweed biomass [13]. Pyrolysis is a thermochemical process that involves the thermal degradation of the biomass components in an inert atmosphere and generates bio-oil, biochar, and gas useful for energy production [13]. Other works have investigated the thermochemical conversion of microalgae biomass to biofuel however, less attention has been paid to the use of macroalgae for that purpose.

In this context, four brown edible seaweeds (Himanthalia elongata (L.) S.F.Gray, Laminaria ochroleuca de la Pylaie, Undaria pinnatifida (Harvey) Suringar, and Saccharina latissima (Linnaeus) C.E. Lane, C. Mayes, Druehl and G.W. Saunders [formerly Laminaria saccharina (L.) Lamouroux], two green (Ulva rigida C. Agardh and Codium tomentosum Stackhouse) and two red species (Porphyra purpurea (Roth) C. Agardh and Palmaria palmata (L.) F. Weber and D. Mohr) (Figure 1) were selected to be valorized in terms of nutritional characterization, thermochemical properties, and bioactive profile, all of them widely distributed throughout Atlantic coastlines and still largely unexplored. To this aim, such seaweeds were evaluated as (1) an alternative renewable resource for biofuel production based on their thermochemical conversion through the pyrolysis pathway and, (2) as a source of bioactive compounds with antioxidant and anti-inflammatory activities. 


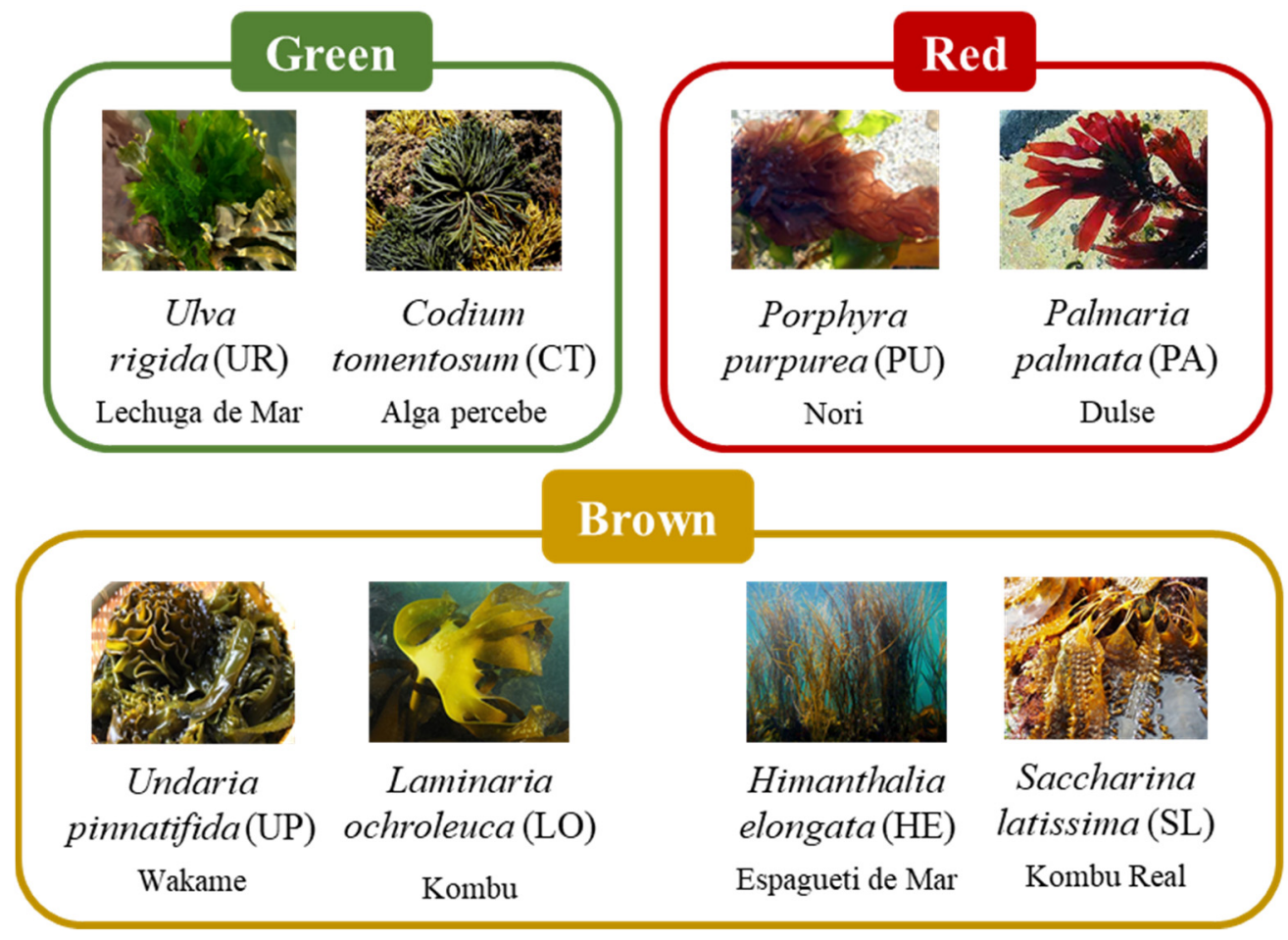

Figure 1. Seaweeds included in this study with their Spanish common names.

\section{Results and Discussion}

\subsection{Nutritional Composition of Seaweeds}

The chemical composition of seaweeds is shown in Table 1. The protein content of the studied macroalgae ranged from 9.81 to $34.79 \mathrm{~g} / 100 \mathrm{~g}$ DW and red algae obtained the highest values. These results are in line with Sanchez-Machado [14] who also reported that the highest protein content corresponded to Porphyra purpurea and Taboada [15] who found $33.2 \mathrm{~g}$ protein/100 g DW for that species [15]. Indeed, the protein values obtained for red macroalgae are comparable to other traditional protein source foods, such as soybean, cereals, eggs, and fish [16]. In contrast, brown algae showed the lowest protein content except for Undaria pinnatifida whose values were like green macroalgae. This was an expected result since Garcia-Vaquero [16] concluded that brown seaweeds had low protein content and within this group, $U$. pinnatifida sample was the species that showed the highest value (up to $24 \mathrm{~g} / 100 \mathrm{~g} \mathrm{DW}$ ). Our results are also comparable to those by Taboada [15] who reported $16.8 \mathrm{~g}$ protein/100 $\mathrm{g} \mathrm{DW}$ for $U$. pinnatifida. All the analyzed seaweeds are a reliable source of carbohydrates, which ranged from 41.54 to $65.92 \mathrm{~g} / 100 \mathrm{~g}$ DW, and brown algae showed the highest values. As polysaccharides synthesis could influence protein formation [16], the highest carbohydrate content observed in brown algae are in consonance with their previously reported low protein values. Likewise, Taboada [15] found that the carbohydrate content of U. pinnatifida and P. purpurea was 53.9 and $44.5 \mathrm{~g} / 100 \mathrm{~g}$ DW, respectively. Seaweed carbohydrates are mainly composed of polysaccharides (in the sulfated and non-sulfated forms depending on the algae species) with a low proportion of di- and monosaccharides [17]. The main polysaccharides from brown algae are alginate, fucoidans, and laminarin [18]. Red seaweeds are rich in agar, carrageenan, sulfated galactans, xylans, and xylogalactans, while green algae contain mainly ulvan [18]. Most of these compounds have been widely explored for their hydrocolloid properties amplifying their use as emulsifiers, stabilizers, and viscosity-controlling ingredients in several applications [19]. In addition, other works have ascribed important bioactivities to macroalgae polysaccharides, such as antioxidant, anti-inflammatory, antitumor, antidiabetic, and antimicrobial activities, suggesting that seaweeds open the door to innovative and technological applications in food, nutrition, and pharmaceutical industries [20]. 
Table 1. Nutritional composition of the studied seaweeds ( $\mathrm{g} / 100 \mathrm{~g}$ dry weight).

\begin{tabular}{cccc}
\hline \multirow{2}{*}{ Seaweed } & \multicolumn{3}{c}{ Nutritional Composition } \\
\cline { 2 - 4 } & Lipids & Protein & Carbohydrates \\
\hline$U R$ & 0.50 & 18.45 & 48.57 \\
$C T$ & 0.61 & 16.36 & 41.54 \\
$U P$ & 1.24 & 16.49 & 52.53 \\
$L O$ & 0.72 & 10.64 & 59.09 \\
$H E$ & 1.74 & 9.81 & 64.30 \\
$S L$ & 0.33 & 10.34 & 65.92 \\
$P U$ & 0.61 & 34.79 & 48.58 \\
$P A$ & 4.22 & 23.55 & 50.41 \\
\hline
\end{tabular}

UR, Ulva rigida; $C T$, Codium tomentosum; UP, Undaria pinnatifida; LO, Laminaria ochroleuca; HE, Himanthalia elongata SL, Saccharina latissima; PU, Porphyra purpurea; PA, Palmaria palmata.

The total lipid content was very low in most of the studied species and ranged from 0.33 to $4.22 \mathrm{~g} / 100 \mathrm{~g}$ DM. Sanchez-Machado [14] reported that the total lipid content of seaweeds is low and represents less than $4 \%$ of dry weight. Among the studied seaweeds, the highest lipid content was observed in Palmaria palmata (4.22\%), and this was comparable with results found by Lopes [21]. Regarding brown algae species, similar lipid contents in Himanthalia elongata, U. pinnatifida and Laminaria ochroleuca $(1.74,1.24$, and $0.72 \mathrm{~g} / 100 \mathrm{~g}$ dry weight, respectively) were observed with respect to the values reported by SanchezMachado [14].

The fatty acids (FAs) composition of the studied seaweeds is displayed in Table 2. Saturated FAs had the main contribution to the total FAs content in all the analyzed species (43.95-64.12\%) except for Ulva rigida (31.84\%) and U. pinnatifida (31.70\%). Palmitic acid (C16:0) was the most abundant compound within this group and P. palmata was the species that showed the highest relative content $(42.05 \%)$. In addition, red algae showed the highest stearic acid content (C18:0). Similar results were found by Sanchez-Machado [14] who reported that saturated FAs were predominant compounds in red macroalgae. Such a result agrees with our results, where the red seaweed P. palmata exhibited the highest content of saturated FAs (Table 2). Regarding monounsaturated FAs (MUFAs), oleic acid (C18:1) was the most abundant MUFA in all the analyzed species and UR showed the main contribution to the total MUFAs obtaining the highest value (29.51\% of total FAs). In line with these results, Yaich [22] found that palmitic and oleic acid in $U$. rigida represented about $76 \%$ of the total FAs. Concerning polyunsaturated FAs (PUFAs), U. pinnatifida showed a predominant contribution to the total PUFAs $(44.92 \%)$ while for the rest of the studied species, PUFAs content ranged from 13.99 to $30.00 \%$ (Table 2). The same tendency was reported by Sanchez-Machado [14] who also found that $U$. pinnatifida showed a significant contribution to the total PUFAs. Linoleic acid (C18:2 $\omega 6)$, an essential fatty acid, was present in all the analyzed seaweeds and brown species (except Saccharina latissima) were those that exhibited the major content. Another essential fatty acid of great interest is linolenic acid (C18:3 w3) which was also present in all the studied macroalgae, and $U$. pinnatifida showed the highest value (24.72\% of total FAs) followed by $U$. rigida $(14.25 \%)$ an $H$. elongata $(11.46 \%)$. These results show that $U$. pinnatifida is a promising source rich in $\omega 3$ fatty acids. On the other hand, docosahexaenoic acid (DHA, C22:6 w3), especially interesting for its contribution to infant brain development, was only detected in P. palmata but in a low relative content $[23,24]$.

Furthermore, interesting results were found for the balance between $\omega 6$ and $\omega 3$ FAs since all the analyzed seaweeds showed low $\omega 6 / \omega 3$ ratio values, below the recommended range (2-5:1). Indeed, P. palmata, Codium tomentosum, $U$. rigida, and $U$. pinnatifida exhibited a $<1$ ratio, due to the higher $\omega 3$ FAs proportion. In the Western diet, the $\omega 6 / \omega 3$ ratio ranges from 15:1 to 20:1 due to the high consumption of $\omega 6$ FAs from terrestrial plants' oils and the insufficient intake of $\omega 3$ FAs [24]. In this regard, the inclusion of the studied seaweeds 
in the diet could potentially contribute to reducing the unbalanced PUFAs ratio and thus, improving the nutritional quality of the Western diet.

Table 2. Fatty acid content of the studied seaweeds (\% of total fatty acid content).

\begin{tabular}{|c|c|c|c|c|c|c|c|c|}
\hline \multirow{2}{*}{ Fatty Acid } & \multicolumn{8}{|c|}{ Seaweed } \\
\hline & UR & $C T$ & $U P$ & $L O$ & $H E$ & $S L$ & $P U$ & $P A$ \\
\hline C12:0 (Lauric acid) & nd & 4.93 & nd & nd & nd & 1.98 & nd & nd \\
\hline C13:0 (Tridecanoic acid) & nd & nd & 0.89 & nd & 0.48 & 0.79 & nd & nd \\
\hline C14:0 (Myristic acid) & nd & 2.49 & 3.97 & 8.59 & 9.55 & 6.62 & nd & 5.74 \\
\hline C15:0 (Pentadecanoic acid) & 1.35 & 0.63 & 0.89 & 0.90 & 0.66 & 1.05 & nd & $n d$ \\
\hline C16:0 (Palmitic acid) & 21.07 & 32.79 & 22.78 & 32.58 & 31.75 & 37.53 & 35.19 & 42.05 \\
\hline C17:0 (Heptadecanoic acid) & nd & 0.22 & nd & nd & 0.32 & 0.90 & nd & nd \\
\hline C18:0 (Stearic acid) & 6.74 & 1.92 & 3.17 & 1.72 & 2.02 & 5.73 & 8.76 & 16.33 \\
\hline C20:0 (Arachidic acid) & nd & 1.46 & nd & 0.61 & 0.72 & 1.90 & nd & nd \\
\hline C21:0 (Heneicosanoic acid) & nd & 1.70 & nd & nd & nd & nd & nd & nd \\
\hline C22:0 (Behenic acid) & 2.68 & 8.79 & nd & nd & 0.88 & nd & nd & nd \\
\hline C24:0 (Lignoceric acid) & nd & 2.72 & nd & nd & 0.63 & nd & nd & nd \\
\hline Sum SATURATED FAs & 31.84 & 57.63 & 31.70 & 44.39 & 47.01 & 56.49 & 43.95 & 64.12 \\
\hline C14:1 (Myristoleic acid) & nd & nd & nd & 0.88 & 0.27 & nd & nd & nd \\
\hline C15:1 (cis-10-Pentadecenoic acid) & 8.88 & 10.53 & 9.65 & 5.70 & 5.53 & 1.54 & 8.55 & 5.03 \\
\hline C16:1 (Palmitoleic acid) & 1.65 & 2.77 & 1.05 & 6.63 & 2.16 & 5.07 & nd & 4.63 \\
\hline C17:1 (cis-10-Heptadecanoic acid) & 1.21 & nd & nd & nd & nd & 0.91 & nd & nd \\
\hline C18:1 trans (trans-9-Elaidic acid) & nd & nd & 0.26 & nd & nd & 0.77 & nd & nd \\
\hline C18:1 cis (Oleic acid) & 29.51 & 14.02 & 12.41 & 18.77 & 15.03 & 21.23 & 17.13 & 9.62 \\
\hline C20:1 (cis-11-Eicosenoic acid) & nd & 0.36 & nd & nd & nd & nd & 3.43 & nd \\
\hline C24:1 (Nervonic acid) & nd & nd & $n d$ & nd & nd & $n d$ & nd & 1.59 \\
\hline Sum MONOUNSATURATED FAs (MUFAs) & 41.26 & 27.67 & 23.38 & 31.97 & 22.99 & 29.51 & 29.11 & 20.87 \\
\hline C18:2 trans (Linolelaidic acid) & nd & nd & nd & nd & 0.12 & nd & nd & nd \\
\hline C18:2 cis (Linoleic acid) & 9.62 & 4.46 & 16.08 & 12.61 & 14.27 & 8.08 & 13.02 & 3.71 \\
\hline C18:3 $\omega 6$ ( $\gamma$-Linolenic acid $)$ & 0.99 & 0.57 & 2.97 & 1.44 & 1.45 & 0.87 & nd & nd \\
\hline C18:3 w3 (Linolenic acid) & 14.25 & 8.53 & 24.72 & 8.09 & 11.46 & 2.79 & 5.24 & 5.61 \\
\hline C20:2 (cis-11,14-Eicosadienoic acid) & nd & 0.60 & nd & 0.50 & 0.22 & nd & 1.90 & nd \\
\hline C20:3 w6 (cis-8,11,14-Eicosatrienoic acid) & nd & 0.27 & 1.15 & 0.64 & 2.30 & 0.84 & 3.62 & nd \\
\hline C20:4 (cis-5,8,11,14-Eicosatetraenoic acid) & 2.04 & 0.25 & nd & 0.35 & 0.17 & 1.41 & 3.16 & 3.53 \\
\hline C22:6 w3 (cis-4,7,10,13,16,19-Docosahexaenoic acid) & nd & nd & nd & nd & nd & nd & nd & 2.17 \\
\hline Sum POLYUNSATURATED FAs (PUFAs) & 26.90 & 14.70 & 44.92 & 23.63 & 30.00 & 13.99 & 26.94 & 15.02 \\
\hline Sum PUFAs $\omega 6$ & 10.61 & 5.30 & 20.19 & 14.69 & 18.15 & 9.79 & 16.64 & 3.71 \\
\hline Sum PUFAs w3 & 14.25 & 8.53 & 24.72 & 8.09 & 11.46 & 2.79 & 5.24 & 7.78 \\
\hline Ratio $\omega 6 / \omega 3$ & 0.74 & 0.62 & 0.82 & 1.81 & 1.58 & 3.50 & 3.18 & 0.48 \\
\hline
\end{tabular}

nd, not detected; UR, Ulva rigida; CT, Codium tomentosum; UP, Undaria pinnatifida; LO, Laminaria ochroleuca; HE Himanthalia elongata; SL, Saccharina latissima; PU, Porphyra purpurea; PA, Palmaria palmata.

The micro- and macro-minerals composition of the studied seaweeds is presented in Table 3. Results suggested that all the analyzed seaweeds are a rich source of nutritionally relevant minerals such as iron, manganese, iodine, calcium, potassium, magnesium, and phosphorus. U. rigida sample recorded the highest values for Fe and $\mathrm{Mn}$ and were greater than those reported by Mæhre [24]. In addition, $U$. rigida was the highest source of $\mathrm{Mg}$, which was also observed by Mæhre [24]. Higher content of macrominerals was observed for all the studied macroalgae when compared to values found for conventional vegetables. In addition, iodine, an essential micronutrient with a key contribution to the synthesis of thyroid hormones, was also present in all the analyzed seaweeds. In fact, great variability in iodine content between and within macroalgae classes was observed which ranged from $82 \mathrm{mg} / \mathrm{kg}$ (P. purpurea) to $5829 \mathrm{mg} / \mathrm{kg}$ (L. ochroleuca). These results were in line with those compiled by Holdt [25] who also stated that Laminaria sp. can accumulate iodine up to 30,000 times the concentration found in seawater. In this context, an excessive consumption of L. ochroleuca and S. latissima could lead to undesirable effects.

In conclusion, variations in nutritional composition between algae species were seen. These differences can be attributed to phyla, harvesting season, environmental conditions, and geographical location. 
Table 3. Composition of elements in the studied seaweeds (mg/kg DM).

\begin{tabular}{|c|c|c|c|c|c|c|c|c|c|c|c|c|}
\hline \multirow{2}{*}{ Seaweed } & \multicolumn{8}{|c|}{ Microelements } & \multicolumn{4}{|c|}{ Macroelements } \\
\hline & Fe & Mn & $\mathrm{Cr}$ & Mo & $\mathrm{Cu}$ & Zn & Se & $\mathbf{I}$ & $\mathrm{Ca}$ & $\mathbf{K}$ & Mg & $\mathbf{P}$ \\
\hline$U R$ & 1177 & 80.1 & 2.5 & $<2$ & 4.12 & 6 & $<4.8$ & 138 & 2778 & 19,792 & 22,932 & 2018 \\
\hline$C T$ & 125 & 32.2 & $<2$ & $<2$ & $<2$ & $<1$ & $<4.8$ & 224 & 5139 & 6794 & 10,426 & 1372 \\
\hline UP & 62 & 8.1 & $<2$ & $<2$ & $<2$ & 28 & $<4.8$ & 154 & 6485 & 65,485 & 4106 & 6604 \\
\hline LO & 28 & 3.7 & $<2$ & $<2$ & $<2$ & 4 & $<4.8$ & 5829 & 8077 & 151,874 & 4660 & 1537 \\
\hline$H E$ & 16 & 17.2 & $<2$ & $<2$ & $<2$ & 25 & $<4.8$ & 189 & 9224 & 73,477 & 8015 & 1393 \\
\hline$S L$ & 31 & 3.0 & $<2$ & $<2$ & $<2$ & 15 & $<4.8$ & 2797 & 8704 & 47,741 & 7162 & 1657 \\
\hline$P U$ & 246 & 28.1 & $<2$ & $<2$ & 7.90 & 33 & $<4.8$ & 82 & 1494 & 33,556 & 3109 & 5867 \\
\hline$P A$ & 177 & 19.7 & $<2$ & $<2$ & 3.92 & 21 & $<4.8$ & 386 & 4756 & 100,836 & 3870 & 3392 \\
\hline
\end{tabular}

UR, Ulva rigida; CT, Codium tomentosum; UP, Undaria pinnatifida; LO, Laminaria ochroleuca; HE, Himanthalia elongata; SL, Saccharina latissima; $P U$, Porphyra purpurea; $P A$, Palmaria palmata.

\subsection{Performance of Seaweeds as an Alternative Bioenergy Resource}

Table 4 depicts the proximate and ultimate analyses of the studied seaweeds. Concerning the proximate analysis, differences in moisture content between algae species were seen and ranged from $5.9 \%$ for $C$. tomentosum to $14.9 \%$ for S. latissima. Although these results are comparable to values reported for other terrestrial biomasses, a low moisture content of the feedstock is preferred for the pyrolysis process [26].

Table 4. Proximate and ultimate analysis of the studied seaweeds.

\begin{tabular}{|c|c|c|c|c|c|c|c|c|c|}
\hline \multirow{3}{*}{ Seaweed } & \multicolumn{4}{|c|}{ Proximate Analysis } & \multicolumn{5}{|c|}{ Ultimate Analysis } \\
\hline & Moisture & Ash & Volatile & Fixed C & $\mathbf{N}$ & $\mathrm{C}$ & $\mathbf{H}$ & O & HHV \\
\hline & $(\%)$ & $(\%)$ & $(\%)$ & $(\%)$ & $(\%)$ & $(\%)$ & $(\%)$ & $(\%)$ & $(\mathrm{MJ} / \mathrm{kg})$ \\
\hline$U R$ & 11.7 & 28.7 & 53.8 & 5.8 & 2.6 & 25.3 & 4.6 & 67.5 & 15.39 \\
\hline$C T$ & 5.9 & 38.9 & 41.3 & 13.9 & 2.5 & 23.1 & 4.4 & 70.0 & 14.07 \\
\hline$U P$ & 9.9 & 27.4 & 49.4 & 13.3 & 2.4 & 24.0 & 3.9 & 69.7 & 16.66 \\
\hline LO & 9.6 & 26.9 & 47.8 & 15.7 & 1.5 & 25.2 & 4.4 & 68.8 & 17.13 \\
\hline$H E$ & 6.8 & 23.6 & 51.8 & 17.8 & 1.5 & 27.3 & 4.7 & 66.5 & 17.56 \\
\hline$S L$ & 14.9 & 20.1 & 50.3 & 14.7 & 1.4 & 27.3 & 5.3 & 66.0 & 19.08 \\
\hline$P U$ & 8.5 & 15.1 & 61.8 & 14.6 & 5.1 & 37.5 & 6.9 & 50.6 & 18.74 \\
\hline$P A$ & 8.7 & 23.8 & 48.4 & 19.1 & 3.4 & 29.5 & 5.2 & 61.8 & 18.12 \\
\hline
\end{tabular}

HHV, Higher heating value determined according to the equation proposed by Cordero [27]; UR, Ulva rigida $C T$, Codium tomentosum; UP, Undaria pinnatifida; LO, Laminaria ochroleuca; HE, Himanthalia elongata; SL, Saccharina latissima; PU, Porphyra purpurea; PA, Palmaria palmata.

Ash content differed between seaweeds species (15.1-38.9\%) and was higher than other biomass generally used for pyrolysis processes (e.g., 3.8-16\% for leaves of various trees, $6.7 \%$ for sugar cane bagasse, $1 \%$ for wood, and $0.8 \%$ for briquette) [26]. This result is in line with that previously mentioned about the higher mineral content of seaweed in comparison to terrestrial plants. The salt content of sea water and rocks, where macroalgae can be generally found, have a significant contribution to this effect [28]. In addition, the analyzed macroalgae species exhibited lower volatile matter content (41.3-61.8\%) than the values reported for terrestrial energy crops (66.8-85.3\%) [26]. This is attributed to the lack of lignocellulosic compounds (cellulose, hemicellulose, and lignin) in seaweeds composition which are structurally predominant in many terrestrial plants. By contrast, unique polysaccharides (previously mentioned) constitute the main carbohydrate fraction of seaweeds and thus, can be depolymerized easier than lignocellulosic plants [10,29]. For acting as a promising energy resource, biofuels should meet two important requirements: present a maximum of $20 \%$ of ash content to avoid operational problems associated with ash composition [26] (e.g., slagging, fouling, sintering, and corrosion) and exhibit a high volatile matter content to be more available to thermal degradation during pyrolysis process [26]. In this context, among the studied seaweeds, P. purpurea showed the lowest ash content 
and the highest volatile matter, suggesting that could be a potential alternative for biofuel production based on the pyrolysis pathway. In addition, a suitable treatment for removing the seaweeds' ash content prior to conducting a pyrolysis process should be designed with a large-scale biofuel production perspective. The proportion of fixed carbon in the studied seaweeds (13.3-19.1\%) are in line with values reported for other terrestrial biomasses, except for $U$. rigida, which showed the lowest fixed carbon value, $<6 \%$ (Table 4 ). For biochar production, fixed carbon is needed to be used as carbonaceous materials during biomass pyrolysis [28]. Thus, based on this parameter, P. palmata could produce more biochar and other pyrolysis products than $U$. rigida.

Regarding ultimate analysis, seaweeds showed lower carbon and hydrogen content and higher nitrogen and oxygen proportion than values reported for other terrestrial biomasses, except for P. purpurea which showed carbon and hydrogen values comparable to content reported for sugar cane straw. For example, the basic elemental composition for typical biomasses used for combustion, such as sugar cane bagasse, wood, and briquette, ranges between $46.7-57.2 \%$ for $\mathrm{C}, 6.1-6.4 \%$ for $\mathrm{H}, 0-1.2 \%$ for $\mathrm{N}$, and $41.5-45.5 \%$ for $\mathrm{O}$ [30]. Nitrogen is present in many biological compounds of seaweeds, such as proteins, chlorophyll, amino acids, and vitamins [30]. Higher nitrogen content could be problematic during the thermochemical conversion of seaweed biomasses since toxic and corrosive nitric oxides (NOx) could be released leading to a negative environmental impact [28].

The high heating values of the analyzed macroalgae were in the range $14.07-19.08 \mathrm{MJ} / \mathrm{kg}$ and were similar to values reported for terrestrial energy crops (17-20 MJ/kg) [29].

Figure 2 displays thermograms from TG, DTG, and DSC analyses that allowed finding the thermochemical behavior of seaweeds during the pyrolysis process. According to the TG curves, all the studied seaweeds showed similar thermochemical behavior, and three stages of biomass pyrolysis were identified. The first stage corresponds to dehydration and evaporation of highly volatile matter and occurred within the range of $20-150{ }^{\circ} \mathrm{C}$. In this stage, small weight loss (in general 10\%) for all samples was recorded. DTG curves confirmed that the biomasses dehydration occurred at $75-100{ }^{\circ} \mathrm{C}$. Complementarily, from DSC analysis, an endothermic point of inflection at $75-100{ }^{\circ} \mathrm{C}$ for all samples was seen, which suggests that seaweeds absorbed heat to evaporate their moisture content (Figure 2). The second stage refers to devolatilization reactions and took place in the range of $175-600{ }^{\circ} \mathrm{C}$. In this stage, the major biomass weight loss as volatile matter was recorded. According to the DTG curves, the maximum weight loss occurred at ca. $250{ }^{\circ} \mathrm{C}$ for all samples and was comparable to values reported by Kebelmann [30] for several macroalgal species. In general, the pyrolytic decomposition of the analyzed seaweeds took place at lower temperatures with respect to the values reported for lignocellulosic biomasses [29] (straws, grasses, woody biomass, etc.) since hemicellulose degrades within the range of 220-260 ${ }^{\circ} \mathrm{C}$ while cellulose degrades at 315-390 ${ }^{\circ} \mathrm{C}$ [30]. Thus, the significant weight loss observed for the analyzed seaweeds is mainly attributed to the marine polysaccharides' decomposition, as previously observed by other authors [31]. In addition, a less intense point of inflection at $320{ }^{\circ} \mathrm{C}$ was detected in the DTG curves of some samples, which could be ascribed to the protein content degradation [29]. As was expected, the organic material degradation follows an exothermic behavior, and thus two peaks at $175^{\circ} \mathrm{C}$ and another at $250-300{ }^{\circ} \mathrm{C}$ was seen in DSC curves for all samples, which was more intense for P. purpurea (Figure 2G), U. rigida (Figure 2A), and U. pinnatifida (Figure 2C). Differences seen in decomposition rates obtained for all seaweeds can be attributed to differences in their chemical composition and natural structure. 

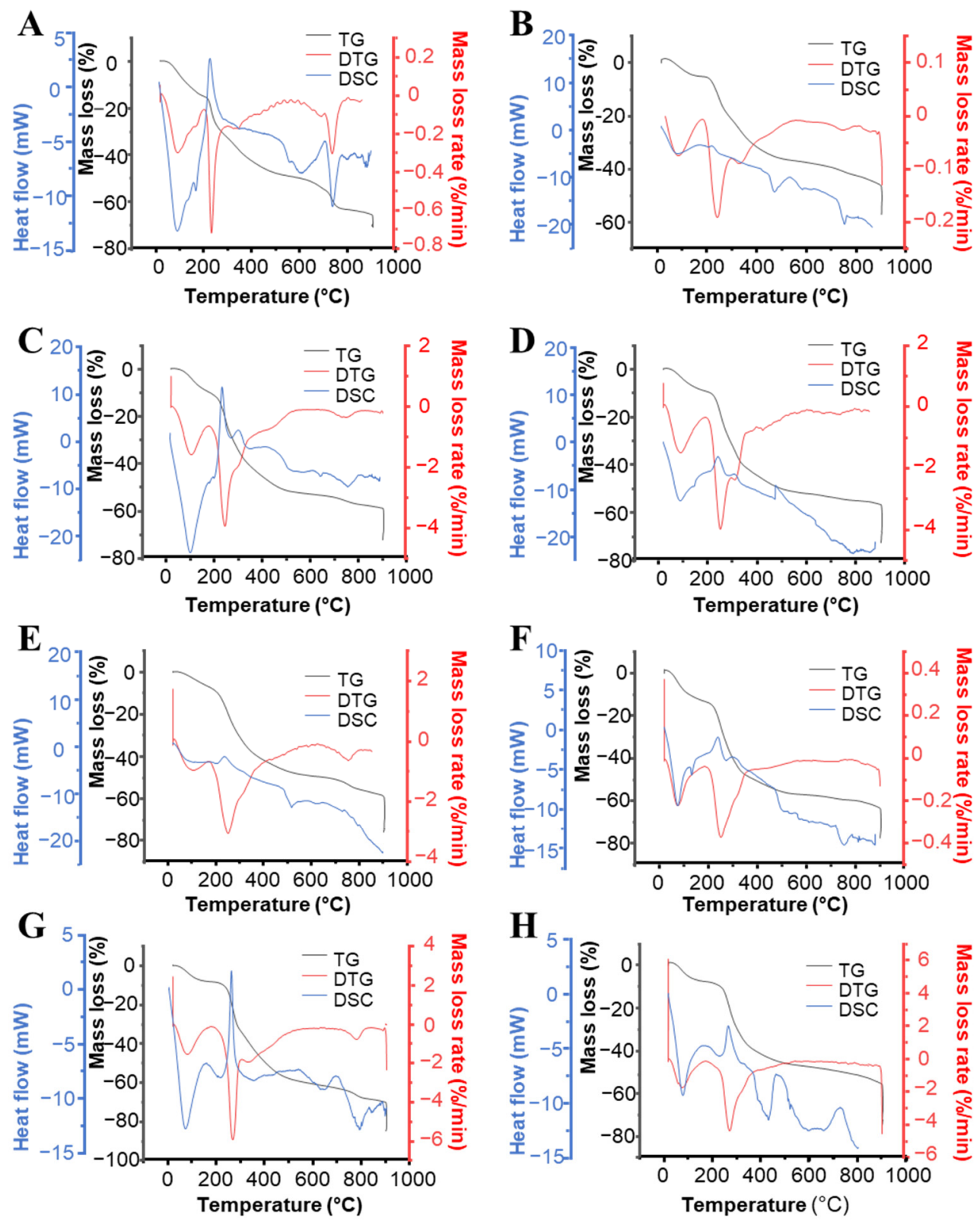

Figure 2. TG, DTG, and DSC curves of the studied seaweeds. Different figures show the studied algae: Part (A), Ulva rigida; (B), Codium tomentosum; (C), Undaria pinnatifida; (D), Laminaria ochroleuca; (E), Himanthalia elongata; (F), Saccharina latissima; (G), Porphyra purpurea; (H), Palmaria palmata.

The third stage corresponds to decomposition of volatile matter released in the previous stage with remaining protein and carbonaceous solids [31]. According to the DTG curves, samples degradation occurred slowly and thus, the weight loss was low (Figure 2). This fact could be ascribed to the slow degradation of the formed residue (biochar) [28]. In addition, some samples showed another point of inflection at $700-800{ }^{\circ} \mathrm{C}$ in the DTG curves which was more intense for $U$. rigida (Figure 2A). This additional mass degradation could be attributed to the devolatilization of inorganic compounds [28], which probably determine the amount of biochar produced [31]. Consistently, an exothermic peak at $700{ }^{\circ} \mathrm{C}$ was seen in DSC curves for some macroalgae, and $U$. rigida recorded the maximum intensity.

\subsection{Performance of Seaweeds as a Promising Source of Bioactive Compounds}

Table 5 shows the extraction yield, total phenolic content, total carotenoid content, and total antioxidant activity obtained for aqueous-organic extracts of the studied seaweeds. 
Significant differences $(p<0.05)$ in the extraction yield were found between seaweed species (regardless of the seaweed class) ranging from 20.55 to $47.29 \%$ (Table 5, Figure S1). This can be ascribed to different polarities and solubility of the bioactive compounds in the mixture of aqueous methanolic and acetonic extracts, as well as to variations in chemical composition among species [32]. S. latissima, L. ochroleuca, and C. tomentosum showed the highest extraction yields (44.30-47.29\%), suggesting a higher release of polar soluble compounds such as phytochemical compounds, polysaccharides, proteins, peptides, and organic acids from these species (Table 5, Figure S1) [32]. By contrast, P. purpurea exhibited the lowest extraction yield ( $20 \%$ ) and could indicate that bioactive compounds may have higher polarity [32], thus requiring more polar solvents for their extraction. However, the extraction yields obtained for all the analyzed seaweeds were higher than the values reported in the literature [33]. Many works have proposed that the extraction procedure of bioactive compounds from biological tissues should combine at least two extraction steps and use aqueous organic solvents with different polarities to extract bioactive compounds with diverse chemical structures [34]. In this regard, the application of heat-assisted extraction in combination with aqueous methanolic and acetonic extracts resulted in an effective procedure for the recovery of bioactive compounds of different structures from seaweeds.

Regarding phenolic compounds, TPC for all the analyzed seaweed ranged from 366.48 to $3448.55 \mu \mathrm{g} / \mathrm{g}$ DM, and significant differences $(p<0.05)$ between species (regardless of the seaweed class) were observed (Table 5, Figure S1). While P. purpurea and H. elongata showed the highest TPC ( 3 mg GAE/g DM), U. rigida, U. pinnatifida, and L. ochroleuca registered the lowest values with no statistical differences between them $(<0.6 \mathrm{mg} \mathrm{GAE} / \mathrm{g}$ $\mathrm{DM})$. As it can be seen in some cases, the extraction yield should not be strictly related to the phenolics content released from seaweeds, thus suggesting the presence of other chemical constituents in the obtained extracts. In this regard, other constituents, such as proteins or reducing sugars in seaweed extracts, can also reduce the Folin-Ciocalteu reagent, overestimating the phenolic content [35]. In addition, other authors reported that the extraction yield may not be correlated with the phytochemical content of extracts [36]. Comparing our results with those values found by other authors is a challenging task due to different extraction procedures used (solvent, temperature, etc.) and the method of expressing results (mg GAE per g extract instead of $\mathrm{g} D \mathrm{DM}$ ). Despite this, some similarities in TPC with other works were found [37]. Polyphenolic compounds such as phlorotannins, bromophenols, flavonoids, phenolic terpenoids, and mycosporine-like amino acids have been found in seaweeds [9]. While phlorotannins are the main polyphenolic group present in brown algae, bromophenols, flavonoids, phenolic terpenoids, and mycosporine-like amino acids were observed in red and green seaweeds [9].

Concerning total carotenoids, significant differences in TCC between seaweed species (regardless of the seaweed class) were also reported, ranging from 61.27 to $295.24 \mu \mathrm{g} / \mathrm{g}$ DM (Table 5, Figure S1). U. rigida, C. tomentosum, L. ochroleuca, and P. purpurea exhibited the highest values (>200 $\mu \mathrm{g} / \mathrm{g}$ DM), while S. latissima and P. palmata presented the lowest TCC $(<80 \mu \mathrm{g} / \mathrm{g}$ DM). These results were higher than those reported by other authors and differences can be attributed to the method used for quantification, the inherent characteristics of species, environmental conditions that algae are exposed to, geographical location, harvesting period, etc. [38]. 
Table 5. Bioactive compound composition and antioxidant activity of the studied seaweeds.

\begin{tabular}{|c|c|c|c|c|c|c|c|}
\hline \multirow{3}{*}{ Seaweed } & \multirow{2}{*}{ Yield } & \multirow{2}{*}{ TPC } & \multirow{2}{*}{ TCC } & \multicolumn{4}{|c|}{ Antioxidant Activity } \\
\hline & & & & DPPH & ABTS & $\beta C$ & CROCIN \\
\hline & $(\%)$ & ( $\mu \mathrm{g} \mathrm{GAE} / \mathrm{g} \mathrm{dw})$ & $(\mu \mathrm{g} \mathrm{C} / \mathrm{g} \mathrm{dw})$ & $I C_{50}(\mathrm{mg} / \mathrm{mL})$ & $I C_{50}(\mathrm{mg} / \mathrm{mL})$ & $(\mathrm{min} / \mathrm{mg} \mathrm{E})$ & $(\mathrm{min} / \mathrm{mg} \mathrm{E})$ \\
\hline$U R$ & $26.58 \pm 1.98^{\mathrm{d}}$ & $366.48 \pm 56.02^{d}$ & $282.61 \pm 54.10^{\mathrm{a}}$ & n.a & n.a & 761.69 & 69.18 \\
\hline$C T$ & $44.30 \pm 1.68^{\mathrm{ab}}$ & $916.62 \pm 121.04 \mathrm{bc}$ & $295.24 \pm 14.80^{\mathrm{a}}$ & n.a & $7.73 \pm 0.10^{g}$ & 190.23 & 59.36 \\
\hline$U P$ & $41.24 \pm 2.87^{b c}$ & $682.56 \pm 51.15^{\mathrm{cd}}$ & $184.85 \pm 20.66^{b c}$ & n.a & $2.01 \pm 0.02 \mathrm{e}$ & 916.91 & 43.98 \\
\hline$L O$ & $44.59 \pm 1.66^{\mathrm{ab}}$ & $527.99 \pm 83.91^{\mathrm{cd}}$ & $229.42 \pm 21.10^{a b c}$ & n.a & $0.50 \pm 0.00^{\mathrm{a}}$ & 266.85 & 43.34 \\
\hline$H E$ & $38.45 \pm 2.57^{c}$ & $3044.29 \pm 387.20^{\mathrm{a}}$ & $134.33 \pm 14.06^{\mathrm{cd}}$ & $5.78 \pm 0.26$ & $0.70 \pm 0.03^{b}$ & 1678.50 & 143.94 \\
\hline$P U$ & $20.55 \pm 0.51^{\mathrm{e}}$ & $3448.55 \pm 241.33^{a}$ & $227.68 \pm 36.95^{a b c}$ & n.a & $3.04 \pm 0.05^{\mathrm{f}}$ & 2401.40 & 210.86 \\
\hline$P A$ & $37.28 \pm 0.58^{c}$ & $931.81 \pm 241.12^{b c}$ & $61.27 \pm 0.04^{\mathrm{d}}$ & n.a & $1.81 \pm 0.01^{\mathrm{d}}$ & 414.16 & 38.36 \\
\hline
\end{tabular}

TPC, Total phenolic content; TCC, total carotenoid content; GAE, gallic acid equivalents; C, carotenoids; $I_{50}$, extract concentration which is required to scavenge $50 \%$ of the DPPH/ABTS radicals. E, algae extract. UR, Ulva rigida; $C T$, Codium tomentosum; UP, Undaria pinnatifida; LO, Laminaria ochroleuca; HE, Himanthalia elongata; SL, Saccharina latissima; PU, Porphyra purpurea; PA, Palmaria palmata. Different letters represent significant differences. 
Carotenoids are considered as the major seaweed pigments, including xanthophylls and carotenes. The main pigment found in brown algae is fucoxanthin which has been widely studied for its promising biological activities, acting as a potent antioxidant, cytoprotective, anticancer, anti-inflammatory, neuroprotective, antidiabetic agent [39]. In addition, $\beta$-carotene was also recorded in brown algae. Among red seaweeds, $\beta$-carotene, $\alpha$-carotene, zeaxanthin, and lutein have been the main carotenoids reported [40]. For green macroalgae, the carotenoid composition includes $\beta$-carotene, lutein, violaxanthin, antheraxanthin, zeaxanthin, and neoxanthin [40]. In this regard, the analyzed seaweeds represent a valuable source of carotenoids with diverse chemical structures which make them interesting alternatives to the artificial colorants commonly used in the food industry, whose controversial safety issues cause rejection among health-concerned consumers. Besides their intense color, they have important health-related properties, being potentially used as functional ingredients.

Regarding DPPH scavenging activity, only H. elongata showed DPPH radical quenching ability among all the studied seaweeds, exhibiting $I C_{50}$ values of $5.78 \pm 0.26 \mathrm{mg} / \mathrm{mL}$ (Table 5). The model parameters and determination coefficient are shown in Table S1. The rest of the samples were not able to achieve the $50 \%$ of radicals scavenging at the studied concentrations. This result suggests that other compounds (namely polysaccharides, proteins) also extracted from seaweeds were partially dissolved in the DPPH methanolic solution and then, interfered in the measurement method. However, better results were obtained for ABTS radical scavenging activity, since most of the analyzed seaweeds showed high radical quenching ability with effective concentrations ranging from 0.50 to $7.73 \mathrm{mg} / \mathrm{mL}$ (Table 5). The model parameters and determination coefficients are shown in Table S1. For instance, L. ochroleuca $\left(I_{50}, 0.50 \mathrm{mg} / \mathrm{mL}\right)$ and H. elongata $\left(I_{50}, 0.70 \mathrm{mg} / \mathrm{mL}\right)$ showed the highest ABTS radical scavenging activity while green algae recorded the lowest values. Indeed, these values were comparable with effective concentrations found by Chakraborty [41] for $\alpha$-tocopherol $\left(I C_{50}, 0.73 \mathrm{mg} / \mathrm{mL}\right)$, indicating that L. ochroleuca and H. elongata may have a similar ability to scavenge ABTS radical as compared to the commonly used antioxidant in the food industry. Based on these results, the high bioactive compounds content (TPC and TCC) of H. elongata could be related to its ABTS radical scavenging activities, suggesting that phenolic and carotenoid compounds may manage the radical deactivation.

Regarding the $\beta$-carotene bleaching inhibition assay, $P$. purpurea recorded the highest antioxidant activity among seaweeds as it was able to delay $\beta$-carotene oxidation by $50 \%$ up to $2401 \mathrm{~min}$ per $\mathrm{mg}$ of extract (Table 5). Similarly, H. elongata, U. pinnatifida and U. rigida also showed a reliable performance, causing an oxidation delay for 1679, 917, and 762 min per mg of extract, respectively. These results suggest that antioxidant compounds with lipophilic nature present in these samples could protect $\beta$-carotene when exposed to the linoleate free radicals and other free radicals produced in the system, therefore delaying lipid oxidation. In this context, these extracts could be further studied for their potential use as natural antioxidants in a real lipid-based system, such as food emulsions, as recently proposed by García-Pérez [42].

Concerning crocin bleaching inhibition assay, P. purpurea was again the species that recorded the highest antioxidant activity, delaying the crocin oxidation by $50 \%$ up to $211 \mathrm{~min}$ per mg of extract (Table 5). H. elongata was also able to prevent the crocin discoloration, extending its protection by $50 \%$ up to $145 \mathrm{~min}$ per $\mathrm{mg}$ of extract. The rest of the species showed low crocin protection since higher amounts of extract should be added to delay the crocin oxidation for a considerable period. This could indicate that antioxidant compounds from these species have lipophilic characteristics since they showed low responses when exposed to aqueous systems [43].

As can be seen, different behaviors of seaweed extract were observed between the four antioxidant activity assays studied. These variations can be attributed that the mixture of phytochemical structures present in seaweed extracts showed different solubility in each solvent used in the antioxidant activity assays (DPPH methanolic solution, ABTS ethanolic 
solution, $\beta$-carotene emulsion, and aqueous crocin solution). This indicates the complex phytochemical structures in seaweed extracts may employ different mechanisms to exert antioxidant activity. For instance, while $U$. rigida showed no DPPH and ABTS antiradical activity, this species was able to delay the $\beta$-carotene oxidation to a greater extent than the rest of the algae.

Concerning the anti-inflammatory and cytotoxic activity of seaweed extracts, results are displayed in Table 6 . In the case of anti-inflammatory activity, only 4 seaweed species showed a moderate performance, being those from P. purpurea and C. tomentosum the most active extracts, exhibiting $I C_{50}$ values of 193 and $264 \mathrm{mg} / \mathrm{mL}$, respectively. However, these results are $>96 \%$ lower than those of dexamethasone, an anti-inflammatory drug used as a positive control (Table 6). The highest activity found for P. purpurea could be motivated by the high rates of phenolic compounds and carotenoids previously described, as it has been proposed by other seaweed species and terrestrial plants [44,45]. Concerning the anti-inflammatory and cytotoxic activity of seaweed extracts, results are displayed in Table 6. In the case of anti-inflammatory activity, only four seaweed species showed a moderate performance, being those from P. purpurea and C. tomentosum the most active extracts, exhibiting $I C_{50}$ values of 193 and $264 \mathrm{mg} / \mathrm{mL}$, respectively. However, these results are $>96 \%$ lower than those of dexamethasone, an anti-inflammatory drug used as a positive control (Table 6).

The highest activity found for P. purpurea could be motivated by the high rates of phenolic compounds and carotenoids previously described, as it has been proposed by other seaweed species and terrestrial plants [44,45]. In this regard, Lee [46] recently determined the anti-inflammatory mechanisms associated with Porphyra extracts, showing a multifaceted mode of action involving nitric oxide scavenging, the inhibition of proinflammatory mediators, and the induction of antioxidant enzymes. On the other hand, the results for the cytotoxic activity of seaweed extracts showed a negligible effect, with effective concentrations $>400 \mathrm{mg} / \mathrm{mL}$ (Table 6). This a priori negative result can be useful in the case of the Vero cell line, as it suggests that macroalgae do not show a cytotoxic effect towards healthy cell lines, which makes their incorporation in food, cosmetic and pharmaceutical products easier from a safety point of view. It is important to note that, despite the lack of activity in these extracts, there is wide evidence about the cytotoxic activity of pure compounds isolated from macroalgae, especially fucoidan, bromophenols, and fucoxanthin [47]. This opens a new perspective for the search of bioactive compounds from seaweeds, tackling the application of purification strategies with the aim of obtaining more active extracts. 
Table 6. Anti-inflammatory and cytotoxic activity of algal extracts.

\begin{tabular}{|c|c|c|c|c|c|c|c|c|c|c|}
\hline \multirow{2}{*}{ Cell Lines } & \multicolumn{7}{|c|}{ Seaweed } & \multicolumn{3}{|c|}{ Control } \\
\hline & UR & $C T$ & $U P$ & $L O$ & $H E$ & $S L$ & $P U$ & $P A$ & Dexa & Ellip \\
\hline \multicolumn{11}{|c|}{ Anti-inflammatory activity $\left(I C_{50}, \mu \mathrm{g} / \mathrm{mL}\right)$} \\
\hline RAW264.7 & $341.8 \pm 20.2^{b}$ & $264.1 \pm 5.6^{\mathrm{a}}$ & $>400$ & $>400$ & $>400$ & $>400$ & $193.1 \pm 4.5^{\mathrm{a}}$ & $368.7 \pm 30.7^{b}$ & $7.2 \pm 0.9$ & - \\
\hline \multicolumn{11}{|c|}{ Cytotoxic activity $\left(G I_{50}, \mu \mathrm{g} / \mathrm{mL}\right)$} \\
\hline Vero & $>400$ & $>400$ & $>400$ & $>400$ & $>400$ & $>400$ & $>400$ & $>400$ & - & $0.35 \pm 0.08$ \\
\hline AGS & $>400$ & $>400$ & $>400$ & $>400$ & $>400$ & $>400$ & $>400$ & $>400$ & - & $0.33 \pm 0.06$ \\
\hline HepG2 & $>400$ & $>400$ & $>400$ & $>400$ & $>400$ & $>400$ & $379.2 \pm 27.2$ & $>400$ & - & $0.23 \pm 0.03$ \\
\hline
\end{tabular}




\section{Materials and Methods}

\subsection{Sample Collection}

Eight common seaweed species from the three main phyla, four brown (Phaeophyceae), two red (Rhodophyta), and two green (Chlorophyta), were kindly provided by Algas Atlanticas AlgaMar S.L. (Pontevedra, Spain, http:/ / www.algamar.com accessed 30 December 2021). Samples of macroalgae were received dry and without natural residues. Once at the laboratory, seaweeds were crushed until obtaining a homogeneous powder with a particle size lower than $2.5 \mathrm{~mm}$. The resulting powders were stored in air-tight plastic bags protected from light at room temperature $\left(25^{\circ} \mathrm{C}\right)$ for further analysis. Figure 1 shows the seaweed species used in this study with their Spanish common names.

\subsection{Nutritional Composition}

\subsubsection{Lipid Content}

Samples ( $2 \mathrm{~g}$ ) were extracted with $100 \mathrm{~mL}$ of n-hexane at $68^{\circ} \mathrm{C}$ for $3 \mathrm{~h}$ using an automatic Soxhlet Büchi Extraction SystemB-811 (Büchi Labortechnik AG, Flawil, Switzerland). Once the solvent was completely recovered using a rotary evaporator, the lipid content was gravimetrically determined. Results were expressed as g/100 g dry matter (DM).

\subsubsection{Fatty Acid Composition}

The fatty acid (FA) composition was evaluated using gas chromatography with flame ionization detector (GC-FID). To carry this out, the lipid-rich extracts obtained by the Soxhlet unit (Section 2.2) were subjected to a derivatization procedure to obtain volatile fatty acid methyl esters (FAMEs). Briefly, $100 \mu \mathrm{L}$ of lipid extracts were mixed with $2 \mathrm{~mL}$ of heptadecanoic acid (HAD) and $4 \mathrm{~mL}$ of n-hexane. The mixture was stirred for $1 \mathrm{~min}$ and then $0.5 \mathrm{~mL}$ of sulfuric acid ( $2 \%$ in methanol) was added. The resulting mixture was stirred for 5 more minutes and then, centrifuged at $3000 \mathrm{rpm}$ for $5 \mathrm{~min}$. Next, $2 \mathrm{~mL}$ of supernatant holding FAMEs were mixed with $5 \mathrm{~mL}$ of n-hexane and stored until analysis.

FAMEs-containing samples were analyzed using a gas chromatograph (Chromatographic System Agilent 7820A) equipped with a column Agilent HP-88 $(60 \mathrm{~m} \times 250 \mu \mathrm{m}$ $\times 0.25 \mu \mathrm{m})$ and a flame ionization detector. The chromatographic run was performed using two temperature programs. The first one consisted of a ramp of $5{ }^{\circ} \mathrm{C} / \mathrm{min}$ until reaching $220^{\circ} \mathrm{C}$ and $15 \mathrm{~min}$ of holding time, while the second one used a temperature ramp of $40{ }^{\circ} \mathrm{C} /$ min until reaching $250{ }^{\circ} \mathrm{C}$ with a holding time of $2 \mathrm{~min}$. Helium was used as carrier gas and was injected at $1 \mathrm{~mL} / \mathrm{min}$. Finally, FA identification was conducted using external standards, and their calibration curve was used to determine FA composition. Results were reported as \% of total fatty acid content.

\subsubsection{Protein Content}

The protein content was found according to the Dumas method. An Elemental Analysis Unit (FISONS Carlo Erba EA1108) with a CHNS Microanalyzer was used for the quantification of $\mathrm{N}_{2}$. Briefly, samples (5 mg) were subjected to flash combustion which led to complete and instantaneous oxidation of organic elements. The combustion gases $\left(\mathrm{O}_{2}\right.$, $\mathrm{CO}_{2}, \mathrm{H}_{2} \mathrm{O}, \mathrm{N}_{2}$, and nitrogen oxides) were collected and passed through traps to remove $\mathrm{O}_{2}, \mathrm{CO}_{2}$, and $\mathrm{H}_{2} \mathrm{O}$. Then, nitrogen oxides were carried by helium over a copper catalyst to convert them into nitrogen. Next, thermal conductivity was found in the mixture, which emits an electrical signal proportional to nitrogen content. The detection limit was $10 \mathrm{ppm}$. A factor of 6.25 was used to convert $\mathrm{mg} \mathrm{N}_{2}$ to protein and thus, results were expressed as $\mathrm{g} / 100 \mathrm{~g}$ DM.

\subsubsection{Carbohydrate Content}

Carbohydrate content (including total fiber) was determined by difference using the data obtained for lipid, protein, and ash content (Section 2.3). 


\subsubsection{Micro- and Micromineral Composition}

The concentration of microelements: iron $(\mathrm{Fe})$, manganese $(\mathrm{Mn})$, chromium $(\mathrm{Cr})$, molybdenum (Mo), coper $(\mathrm{Cu})$, zinc $(\mathrm{Zn})$, and selenium (Se); and macroelements: calcium $(\mathrm{Ca})$, potassium $(\mathrm{K})$, magnesium $(\mathrm{Mg})$, and phosphorus $(\mathrm{P})$ were simultaneously analyzed by inductively coupled plasma optical emission spectrometry (ICP-OES) using a Perkin-Elmer Optima 4300 DV spectrometer (Shelton, CT, USA), equipped with an AS-90 autosampler, axial system, a high dynamic range detector and a cross-flow type nebulizer for pneumatic nebulization.

The ICP-OES assessment was performed following the procedure described by Millos [48]. Prior to ICP-OES analyses, samples $(0.25 \mathrm{~g})$ were digested with concentrated nitric acid $\left(\mathrm{HNO}_{3}\right)$ and hydrogen peroxide using a Multiwave 3000 oven (Anton Paar, Graz, Austria), equipped with eight digestion vessels, according to the methodology proposed by Millos [48]. Next, elements were analyzed by ICP-OES (axial configuration) and the equipment operating conditions for ICP-OES used in this study were those reported by Millos [48]. For the quantification of micro- and macroelements, standard stock solutions with the addition of ${ }^{115} \mathrm{In}$ as an internal standard were used to construct the corresponding calibration curves. Results were reported as $\mathrm{mg} / \mathrm{kg} \mathrm{DM}$.

In turn, the concentration of iodine (I) was conducted by inductively coupled plasmamass spectrometry (ICP-MS) using a Thermo Elemental X7 Series ICP-MS equipped with an ASX-520 autosampler (Omaha, NE, USA) and PlasmaLab Software. Samples (0.25 g) were digested with tetramethylammonium hydroxide (TMAH) in closed vessels. Both the operating conditions and ICP-MS measurement were carried out following the method proposed by Millos [49].

These studies were conducted in the Food Security and Sustainable Development Laboratory, Scientific and Technological Support Centre for Research (SSADS-CACTI, University of Vigo, Vigo, Spain).

\subsection{Performance of Seaweeds as an Alternative Bioenergy Resource}

The potential of seaweeds biomass as a resource for sustainable biofuel production was studied. For the conversion of biomass to fuel, a pyrolysis process was checked that is, dry seaweeds were heated in the absence of air and the thermal decomposition of the organic components was evaluated. Proximate and ultimate analyses were conducted to evaluate the chemical properties of seaweed biomasses in the pyrolysis process which allow inferring about their suitability for biofuel production.

\subsubsection{Proximate Analysis}

Moisture content: The moisture content of samples was thermogravimetrically determined according to the UNE-EN 14774-1 standardized procedure, using a SETSYS Evolution apparatus (Setaram Instrumentation, Caluire-et-Cuire, France). Samples (7-15 mg) were heated to $105{ }^{\circ} \mathrm{C}$ at $10{ }^{\circ} \mathrm{C} / \mathrm{min}$ under an inert nitrogen flow $(30 \mathrm{~mL} / \mathrm{min})$ until constant weight.

Volatile matter: The volatile matter was thermogravimetrically determined according to the UNE-EN 15,148 standardized procedure in a SETSYS Evolution apparatus (Setaram Instrumentation, Caluire-et-Cuire, France). Water-free samples (7-15 mg) were heated between 105 and $600{ }^{\circ} \mathrm{C}$ at $10{ }^{\circ} \mathrm{C} / \mathrm{min}$ under an inert nitrogen flow $(30 \mathrm{~mL} / \mathrm{min})$ until constant weight.

Ash content: The ash content was also thermogravimetrically measured following the procedure described in UNE-EN 14775 . Water- and volatile matter-free samples (7-15 mg) were combusted at $900{ }^{\circ} \mathrm{C}$ under oxidizing air atmosphere $(30 \mathrm{~mL} / \mathrm{min})$ until constant weight.

Fixed carbon: Fixed carbon was calculated by difference using the data obtained above for moisture content, volatile matter, and ash content. 


\subsubsection{Ultimate Analysis}

Basic elemental composition: The amount of carbon $(\mathrm{C})$, hydrogen $(\mathrm{H})$, nitrogen $(\mathrm{N})$ in samples were measured in an Elemental Analysis Unit FISONS Carlo Erba EA1108 (FISONS, Milan, Italy) with a CHNS Microanalyzer. The oxygen $(\mathrm{O})$ content was determined by subtracting the sum of the other element contents from $100 \%$.

Higher heating value: The higher heating values (HHV) of samples were calculated through a simple Equation (1) based on data obtained from proximate analysis as proposed by Cordero [27], in which volatile matter (VM) and ash are used, and the results were reported as $\mathrm{MJ} / \mathrm{kg}$.

$$
\mathrm{HHV}=\frac{35,430-183.5 \times \mathrm{VM}-354.3 \times \mathrm{ASH}}{1000}
$$

Thermal analysis: The thermochemical characterization of seaweeds was studied through thermogravimetric (TG), derivative thermogravimetric analyses (DTG), and differential scanning calorimetry (DSC) in the simultaneous thermal analyzer SETSYS Evolution (Setaram Instrumentation, Caluire-et-Cuire, France). Non-isothermal assays were performed by heating samples $\left(7-15 \mathrm{mg}\right.$ ) at ramp rates of $10^{\circ} \mathrm{C} / \mathrm{min}$, in the temperatures range of $20-900{ }^{\circ} \mathrm{C}$ using nitrogen as carrier gas $(30 \mathrm{~mL} / \mathrm{min})$. Then, isothermal experiments were performed at $900{ }^{\circ} \mathrm{C}$ under oxidizing air atmosphere $(30 \mathrm{~mL} / \mathrm{min})$. The sample weight and furnace temperature were registered during thermal analysis. TGA, DTG, and DSC thermograms were plotted that show the mass loss $(\%)$, the mass loss rate $(\% / \mathrm{min})$, and heat flow $(\mathrm{mW})$, respectively, during thermal analysis.

\subsection{Evaluation of Seaweeds as a Promising Source of Bioactive Compounds}

Total phenolic content (TPC), total carotenoid content (TCC), antioxidant, antiinflammatory, and cytotoxic activities were found on aqueous-organic extracts of the studied seaweeds.

Heat-assisted extraction was performed according to the methodology described by Perez-Jimenez [34] with some modifications. Samples $(1 \mathrm{~g})$ were placed in amber glass bottles with $20 \mathrm{~mL}$ of acidified aqueous methanol $(50 \% v / v, \mathrm{pH}=2)$ (Carlo Erba Reagents, Milan, Italy) to obtain a solid/liquid ratio of $50 \mathrm{~g} / \mathrm{L}$. The bottles holding the mixture were placed in a thermostatic water bath at $40{ }^{\circ} \mathrm{C}$ and stirred using a magnetic stirrer for $1 \mathrm{~h}$. Then, the resulting mixtures were transferred to Falcon tubes to be centrifugated at $6000 \mathrm{rpm}$ for $15 \mathrm{~min}$. The supernatants were recovered, and $20 \mathrm{~mL}$ of aqueous acetone $(70 \%$ $v / v)$ (Carlo Erba Reagents, Milan, Italy) was added to residues. The new mixtures were subjected to the same extraction procedure stated before. Then, methanolic and acetonic extracts were combined and used to find the extractable bioactive compounds described above and their associated bioactivities.

The extraction yield was thermogravimetrically determined according to the methodology explained by Silva [33] and was calculated using Equation (2) and expressed as g extract/100 g dry weight. Determinations were conducted in duplicate.

$$
\text { Yield }(\%)=\frac{\mathrm{P}_{\mathrm{t}=24 \mathrm{~h}}-\mathrm{P}_{\mathrm{t}=0}}{\left(\frac{\mathrm{m}_{\mathrm{sw}} \times \mathrm{V}_{\mathrm{a}}}{\mathrm{V}_{\mathrm{sv}}}\right) \times\left(\frac{100-\mathrm{MC}_{\mathrm{sw}}}{100}\right)} \times 100
$$

where,

$\mathrm{P}_{\mathrm{t}=0}$ : mass of crucible before adding the extracted solution

$\mathrm{P}_{\mathrm{t}=24 \mathrm{~h}}$ : mass of crucible after $24 \mathrm{~h}$ of drying

$\mathrm{m}_{\mathrm{sw}}$ : mass of dry seaweed

$\mathrm{V}_{\mathrm{a}}$ : volume of extracted solution aliquot $(5 \mathrm{~mL})$

$\mathrm{V}_{\mathrm{sv}}$ : volume of solvents used for extraction $(40 \mathrm{~mL})$

$\mathrm{MC}_{\mathrm{sw}}$ : moisture content (\%) of each seaweed 


\subsubsection{Total Phenolic Content}

TPC was spectrophotometrically determined using the Folin-Ciocalteu reagent (FCR) (VWR Chemicals, Fontenary-Sous-Bois, France) according to the methodology described by Cassani [50]. Briefly, $25 \mu \mathrm{L}$ of each extract (serially diluted with water) was added to $125 \mu \mathrm{L}$ of FCR (diluted in water, 1:10). After 3 min of incubation at room temperature, $100 \mu \mathrm{L}$ of $\mathrm{Na}_{2} \mathrm{CO}_{3}$ solution $(7.5 \% \mathrm{w} / \mathrm{v}$ ) (Carlo Erba Reagents, Milan, Italy) was added and the reaction mixture was incubated for $2 \mathrm{~h}$ at the same temperature. Absorbance was measured at $765 \mathrm{~nm}$ using a Synergy HTX multi-mode reader (Bio-Tek, Winooski, VT, USA). TPC was calculated using gallic acid as standard. The calibration curve of gallic acid was made up in the range of $5-100 \mu \mathrm{g} / \mathrm{mL}$. Results were reported as $\mu \mathrm{g}$ gallic acid (Merck, Darmstad, Germany) equivalents (GAE)/g DM. Determinations were conducted in duplicate.

\subsubsection{Total Carotenoid Content}

TCC was spectrophotometrically found and thus, the absorbance of extracted solutions was measured at $450 \mathrm{~nm}$ using a Synergy HTX multi-mode reader (Bio-Tek, Winooski, VT, USA). TCC was calculated according to Equation (3) proposed by Scott [51]. Results were reported as $\mu \mathrm{g}$ total carotenoids/g DM. Determinations were conducted in duplicate.

$$
\mathrm{TCC}=\frac{\mathrm{A}_{450}}{2500} \times 10 \frac{\mathrm{mg}}{\mathrm{mL}} \times \frac{\mathrm{V}_{\mathrm{sv}}}{\mathrm{m}_{\mathrm{sw}} \times \frac{100-\mathrm{MC}_{\mathrm{sw}}}{100}}
$$

where,

$\mathrm{A}_{450}$ : absorbance measured at $450 \mathrm{~nm}$

$\mathrm{m}_{\mathrm{sw}}$ : mass of dry seaweed

$\mathrm{V}_{\mathrm{sv}}$ : volume of solvents used for extraction $(40 \mathrm{~mL})$

$\mathrm{MC}_{\mathrm{sw}}$ : moisture content (\%) of each seaweed

\subsubsection{Antioxidant Activity}

Total antioxidant activity of seaweeds was studied through four assays: the scavenging activity of the stable 1,1-diphenyl-2-picrylhydrazyl (DPPH) radical, the Trolox equivalents antioxidant capacity (TEAC), $\beta$-carotene, and crocin bleaching antioxidant assays.

DPPH assay

A stock methanolic solution $(7.61 \mathrm{mM})$ of DPPH radical (Alfa Aesar, Thermo Fisher, Kandel, Germany) was prepared. Then, the stock reagent was diluted 1:50 with methanol to obtain 1.4 units of absorbance measured at $515 \mathrm{~nm}$. The reaction was conducted in 96-well microplates, where $50 \mu \mathrm{L}$ of each extract (serially diluted with methanol) was mixed with $200 \mu \mathrm{L}$ of the DPPH stock solution. The resulting mixture was incubated at room temperature in the dark for $60 \mathrm{~min}$. Absorbance was measured at $515 \mathrm{~nm}$ at once after mixing $(t=0)$ and after 60 min using a Synergy HTX multi-mode reader (Bio-Tek, Winooski, VT, USA). A control sample was also prepared by replacing the sample with solvent. The scavenging activity of seaweed extracts was calculated following Equation (4).

$$
\operatorname{DPPH}(\%)=\left(\frac{\mathrm{A}_{\mathrm{c}}-\mathrm{A}_{\mathrm{s}}}{\mathrm{A}_{\mathrm{c}}}\right) \times 100
$$

where,

$A_{c}$ : absorbance of control at $t=0$

$\mathrm{A}_{\mathrm{s}}$ : absorbance of sample at $\mathrm{t}=60 \mathrm{~min}$

DPPH scavenging activity $(\%)$ vs. extract concentration $(\mathrm{mg} / \mathrm{mL})$ were plotted for all seaweeds to model data. Linear and non-linear methods (Equations (5) and (6), respectively) were used to adjust experimental data.

$$
\mathrm{Y}=\mathrm{a} \times \mathrm{X}+\mathrm{b}
$$




$$
\mathrm{Y}=\mathrm{a} \times \ln (\mathrm{X})+\mathrm{b}
$$

where, $a$ and $b$ are the model parameters.

From these studies, the model parameters and determination coefficients $\left(\mathrm{R}^{2}\right)$ were obtained for each seaweed and the effective concentration value $\left(I C_{50}\right)$, which refers to the extract concentration needed to scavenge $50 \%$ of DPPH radicals, was determined.

TEAC assay

This method is based on the antioxidant compounds' ability to scavenge the ABTS ${ }^{\bullet+}$ radical, compared with Trolox's scavenging ability, an analog of vitamin E. This method was carried out following the methodology proposed by Cassani [35]. In this regard, the ABTS ${ }^{\bullet+}$ radical was produced by the interaction of ABTS $(19.3 \mathrm{mg}$ ) (Alfa Aesar, Thermo Fisher, Kandel, Germany) dissolved in $5 \mathrm{~mL}$ of distilled water and $88 \mu \mathrm{L}$ of potassium persulfate $\left(\mathrm{K}_{2} \mathrm{~S}_{2} \mathrm{O}_{8}, 0.0378 \mathrm{~g} / \mathrm{mL}\right)$ (Carlo Erba Reagents, Milan, Italy). The radical solution was incubated at room temperature for $16 \mathrm{~h}$. Then, $250 \mu \mathrm{L}$ of the activated ABTS ${ }^{\bullet+}$ radical was mixed with $10 \mathrm{~mL}$ of ethanol (Carlo Erba Reagents, Milan, Italy). Under these conditions, the absorbance of the reagent solution is $\sim 1.4$ measured at $734 \mathrm{~nm}$. The reaction was produced by adding $200 \mu \mathrm{L}$ of the previously prepared ABTS $^{\bullet+}$ radical solution and $50 \mu \mathrm{L}$ of extract solutions (serially diluted with ethanol) in 96-well microplates. Immediately after mixing $(t=0)$ and after 60 min of incubation at room temperature, absorbance at $734 \mathrm{~nm}$ was measured using a Synergy HTX multi-mode reader (Bio-Tek, Winooski, VT, USA). A control sample was also prepared by replacing the sample with solvent. The ABTS scavenging activity of seaweed extracts was also calculated according to Equation (4) and linear and non-linear methods (Equations (5) and (6)) were also used to adjust experimental data derived from the plot of ABTS scavenging activity (\%) vs. extract concentration $(\mathrm{mg} / \mathrm{mL})$. Similar to the DPPH assay, the model parameters and determination coefficients $\left(\mathrm{R}^{2}\right)$ were obtained for each seaweed and the effective concentration value $\left(I C_{50}\right)$, which refers to the extract concentration needed to scavenge $50 \%$ of ABTS radicals, was determined.

$\beta$-carotene bleaching assay

This method is based on the ability of antioxidant compounds present in seaweed extracts to delay the oxidative discoloration of $\beta$-carotene in a $\beta$-carotene/linoleic acid emulsion. Linoleic acid is easily oxidized at $50{ }^{\circ} \mathrm{C}$ and the radicals formed may react with the unsaturated $\beta$-carotene chain causing its oxidation with the corresponding decrease in absorbance at $470 \mathrm{~nm}$. In presence of an antioxidant compound source, $\beta$-carotene oxidation is delayed since antioxidants may neutralize the linoleate free radical and other free radicals formed in the oxidation reaction [32]. Thus, this method is suitable for studying the capacity of lipophilic antioxidants to protect the $\beta$-carotene molecule and inhibit or delay lipid oxidation [52].

For this purpose, a stock solution of $\beta$-carotene (Tokyo Chemical Industry C.O., Tokyo, Japan) was prepared by mixing $\beta$-carotene $(4 \mathrm{mg})$, Tween-40 (4 g) (Carlo Erba Reagents, Milan, Italy), linoleic acid (0.5 mL) (Acros organics, Morris Planes, NJ, USA) and chloroform (20 mL) (Carlo Erba Reagents, Milan, Italy) in a round-bottomed flask following the methodology proposed by Prieto [53]. Then, chloroform was completely recovered using a rotary evaporator at $45^{\circ} \mathrm{C}$ for $15 \mathrm{~min}$. An aliquot $(0.25 \mathrm{~mL})$ of the resulting oily residue was vigorously shaken with $30 \mathrm{~mL}$ of preheated Milli-Q water $\left(45^{\circ} \mathrm{C}\right)$ having $100 \mathrm{mM}$ of phosphate buffer $(\mathrm{pH}=6.5)$. Under these conditions, the absorbance of the $\beta$-carotene solution is $\sim 1.4$, measured at $470 \mathrm{~nm}$. The reaction mixture was produced by adding $200 \mu \mathrm{L}$ of the previously prepared $\beta$-carotene solution and $50 \mu \mathrm{L}$ of sample (serially diluted with solvent) in 96-well microplates. The absorbance of the final reaction was at once determined after mixing $(\mathrm{t}=0)$ at $470 \mathrm{~nm}$ using a Synergy HTX multi-mode reader (Bio-Tek, Winooski, VT, USA). Then, microplates were incubated at $45^{\circ} \mathrm{C}$ under continuous shaking (85 rpm) and successive absorbance measurements were conducted at regular intervals (20 min) for $200 \mathrm{~min}$. A control sample was also prepared, by replacing the sample with solvent [53]. 
For quantification, the time course of the oxidative response was defined according to Equation (7).

$$
R=1-\frac{\mathrm{S}_{\mathrm{t}}}{\mathrm{S}_{0}}
$$

where, $S_{0}$ and $S_{t}$ are the substrate ( $\beta$-carotene) concentrations at times 0 and $t$, respectively.

Then, the oxidative response (Equation (7)) was adjusted to a kinetic profile based on the Weibull mass function, Equation (8), according to the method explained by Prieto [53].

$$
R=\mathrm{K} \times\left(1-e^{-(\ln 2) \times\left(\frac{t}{\tau}\right)^{\alpha}}\right)
$$

where,

K: asymptote

$\tau$ : time when $50 \%$ oxidation is achieved

$\alpha$ : shape parameter associated with the maximum slope of the response $\left(v_{\max }\right)$

The parameters of Weibull models were fitted using the non-linear least-squares (quasiNewton) method provided by the macro-Solver of the Microsoft Excel 2016 spreadsheet. Determinations were conducted in duplicate and results were expressed as the time (min) when $50 \%$ oxidation was achieved per mg of extract.

Crocin bleaching assay

The basis of this method is like that previously explained for the $\beta$-carotene assay. In this sense, $2,2^{\prime}$-Azobis(2-amidinopropane) dihydrochloride (AAPH) is used as a free radical source that can induce crocin oxidation (substrate) with the corresponding decrease in absorbance at $450 \mathrm{~nm}$. In the presence of antioxidants, crocin oxidation is delayed since antioxidants react with the formed radicals. This method is suitable to analyze the performance of hydrophilic antioxidants on protecting crocin against free radicals.

To carry this out, crocin $(100 \mu \mathrm{mol} / \mathrm{L})$ (Tokyo Chemical Industry C.O., Tokyo, Japan) and AAPH (7.68 mmol/L) (Acros organics, Morris Planes, NJ, USA) solution were dissolved and mixed in $30 \mathrm{~mL}$ of preheated Milli-Q water $\left(40{ }^{\circ} \mathrm{C}\right)$ containing $100 \mathrm{mM}$ of phosphate buffer ( $\mathrm{pH}=5.5$ ), according to the methodology proposed by Prieto [54]. It is worth mentioning that the resulting mixture should be prepared just before use to avoid the degradation of any reagent. Under these conditions, the absorbance of the reagent solution is $\sim 1.4$, measured at $450 \mathrm{~nm}$. The reaction mixture was produced by adding $200 \mu \mathrm{L}$ of the previously prepared reagents solution and $50 \mu \mathrm{L}$ of sample (serially diluted with solvent) in 96-well microplates. The absorbance of the final reaction was at once determined after mixing $(\mathrm{t}=0)$ at $450 \mathrm{~nm}$ using a Synergy HTX multi-mode reader (Bio-Tek, Winooski, VT, USA). Then, microplates were incubated at $37{ }^{\circ} \mathrm{C}$ under continuous shaking ( $\left.85 \mathrm{rpm}\right)$ and successive measurements were conducted at regular intervals $(20 \mathrm{~min})$ for $120 \mathrm{~min}$. A control sample was also made by replacing the sample with solvent. For quantification, data were fitted to the Weibull method as previously described, and results were expressed as the time ( $\mathrm{min}$ ) when $50 \%$ oxidation was achieved per mg of extract. Determinations were conducted in duplicate.

\subsubsection{Anti-Inflammatory Activity}

The anti-inflammatory activity of seaweed extracts was determined as a function of the inhibition of nitric oxide (NO) production by lipopolysaccharide (LPS)-induced RAW264.7 macrophages cell line, as described by Garcia-Perez [44]. For the purpose, extracts were lyophilized to obtain the dry residue, which was resuspended in water and assessed at four concentrations, ranging $0.125-0.4 \mathrm{mg} / \mathrm{mL}$. The murine macrophage cell line was cultured in DMEM medium (Dulbecco's Modified Eagle Medium, Gibco, UK) supplemented with 10\% heat-inactivated fetal bovine serum (Fisher Scientific, Loughborough, UK), 1\% L-glutamine (200 mM) (Gibco, Fisher Scientific, Madrid, Spain), 1\% MEM essential amino acid solution (100X) (Gibco, UK), and 1\% antibiotic solution (Fisher Scientific, Rochester, NY, USA) holding $50 \mathrm{U} / \mathrm{mL}$ streptomycin and $100 \mathrm{mg} / \mathrm{L}$ streptomycin. Cells were kept at $37{ }^{\circ} \mathrm{C}$ under a humidified $5 \% \mathrm{CO}_{2}$ atmosphere, and cell density was adjusted at $5 \times 10^{5}$ cells $/ \mathrm{mL}$ 
after assessing cell viability was $>99 \%$ according to Trypan blue exclusion assay. The cell suspension was later seeded in 96-well microplates to reach an experimental cell density of $1.5 \times 10^{5}$ cells / well and incubated in the same conditions for $24 \mathrm{~h}$. Afterward, cells were treated with algal extracts and incubated for $1 \mathrm{~h}$, and further stimulated by LPS (Enzo Life Sciences Inc., New York, NY, USA), which was added at $1 \mathrm{mg} / \mathrm{mL}$, and incubated for $18 \mathrm{~h}$. Dexamethasone was used as a positive control. In all cases, dexamethasone, the extracts, and LPS were diluted in supplemented DMEM medium. The NO determination was found in the cell supernatants using the Griess reagent system kit (Promega, Madison, WI, USA), following the manufacturers' instructions. All determinations were conducted in triplicate and results were expressed as effective concentration $\left(I C_{50}\right)$, which stands for the extract concentration required to inhibit by $50 \%$ the NO production caused by LPS induction, in $\mu \mathrm{g} / \mathrm{mL}$.

\subsubsection{Cytotoxic Activity}

Three cancer cell lines and one non-tumor cell line were employed to assess the cytotoxic activity of seaweed extracts, applying the sulforhodamin B (SRB) cytotoxicity assay, namely: the African green monkey kidney-derived Vero cell line, the human gastric cancer AGS cell line, the human lung adenocarcinoma A549 cell line, and the human hepatocarcinoma HepG2 cell line. Vero, A549, and HepG2 were routinely kept in DMEM medium, while AGS was cultured in RPMI-1640 medium, both supplemented as stated above and incubated as previously described. A cell suspension with $5 \times 10^{4}$ cells $/ \mathrm{mL}$ was obtained and the viability was assessed at $>99 \%$ using Trypan blue exclusion assay and plated in a 96-well microplate with different concentrations of algal extracts, ranging 0.125-0.4 mg/mL, for $48 \mathrm{~h}$ under the same conditions. Ellipticine (Enzo, USA) was used as a positive control. After incubation, $100 \mu \mathrm{L}$ of cold $10 \%$ trichloroacetic acid (Fisher Chemical Reagents, Pittsburgh , USA) were added and the mixture was incubated for $1 \mathrm{~h}$ at $4{ }^{\circ} \mathrm{C}$ to allow cell attachment. Afterward, the mixture was removed and $100 \mu \mathrm{L}$ of $0.057 \%(w / v)$ SRB (Alfa Aesar, Thermo Fisher, Germany) prepared in 1\% acetic acid, and samples were incubated at room temperature for 30 min to allow cell staining. Finally, the SRB excess was removed washing three times with $1 \%$ acetic acid (Fisher Chemical Reagents, Pittsburgh , USA), and the remaining SRB was redissolved in $200 \mu \mathrm{L}$ of $10 \mathrm{mM}$ Tris solution for $30 \mathrm{~min}$ in an orbital shaker at $250 \mathrm{rpm}$. The absorbance of samples was measured at $540 \mathrm{~nm}$ in a Synergy HTX multi-mode reader (Bio-Tek, Winooski, VT, USA). All determinations were conducted in triplicate and results were expressed as growth inhibitory $50\left(G_{50}\right)$ concentration, which stands for the extract concentration needed to inhibit cell growth by $50 \%$, in $\mu \mathrm{g} / \mathrm{mL}$.

\subsection{Statistical Analysis}

Three independent experimental runs with each experiment performed at least in duplicate were carried out. Results were reported as mean values \pm standard deviation (SD). R software version 2.12 (R Development Core Team, 2011) was used to analyze data. Analysis of variance (ANOVA one-way, $p<0.05$ ) and Tukey-Kramer comparison test were performed to study the matrix effect on extraction yield, TPC, TCC, antioxidant, anti-inflammatory, and cytotoxic activities of samples.

\section{Conclusions}

The present work shows that some seaweed species have a high content of polysaccharides (including total fiber), low fat content, moderate protein content, a high proportion of $\omega 3$ fatty acids, which favors a healthy $\omega 6: \omega 3$ ratio, and high content of essential minerals. This supports their use as food or functional ingredients to improve certain nutritional properties in food formulations, as well as for the extraction of their biological compounds.

Concerning thermal characterization, three biomass decomposition stages were identified with the maximum degradation rate recorded at $250{ }^{\circ} \mathrm{C}$. These values were lower than those reported for terrestrial energy crops, due to different polysaccharide compositions, 
in particular the lack of hemicellulose and lignin in the carbohydrate profile. Macroalgae species with the lowest ash content and highest volatile matter and fixed carbon could be promising resources for alternative biomass-based renewable fuel production with the added advantages of having higher growth rates, no requirements of arable land for cultivation, and higher carbon dioxide mitigation ability over terrestrial biomasses.

Regarding bioactive compounds, high extraction yield for most of the seaweeds was recorded suggesting a higher release of polar soluble compounds such as phytochemical compounds, polysaccharides, proteins, peptides, and organic acids from these species. Different behaviors of seaweed extracts were seen between the four antioxidant activity assays studied. The complex phytochemical structures present in seaweed extracts may have different solubility in each solvent used in the antioxidant activity assays. It is noteworthy that $H$. elongata showed the highest phytochemical content and antioxidant activities among the studied species. By contrast, P. purpurea showed moderate performance on anti-inflammatory activity.

Supplementary Materials: The following supporting information can be downloaded at: https: //www.mdpi.com/article/10.3390/ijms23042355/s1.

Author Contributions: Conceptualization, L.C. and M.A.P.; methodology, C.L.-L., M.B.-M., F.C. and P.G.-P.; formal analysis, L.C., P.G.-P. and M.A.P.; investigation, L.C., C.L.-L. and P.G.-P.; resources, M.A.P. and J.S.-G.; data curation, L.C., C.L.-L. and P.G.-P.; writing-original draft preparation, L.C., C.L.-L. and P.G.-P.; writing-review and editing, L.C., C.L.-L. and M.A.P.; supervision, M.A.P.; project administration, M.A.P. and J.S.-G.; funding acquisition, M.A.P. and J.S.-G. All authors have read and agreed to the published version of the manuscript.

Funding: This research was funded by Ibero-American Program on Science and Technology, grant number: CYTED_AQUA-CIBUS, P317RT0003, and by the Bio Based Industries Joint Undertaking (JU) under grant agreement No 888003 UP4HEALTH Project (H2020-BBI-JTI-2019) that supports the work of C. Lourenço-Lopes. The JU receives support from the European Union's Horizon 2020 research and innovation program and the Bio Based Industries Consortium.

Institutional Review Board Statement: Not applicable.

Informed Consent Statement: Not applicable.

Data Availability Statement: Not applicable.

Acknowledgments: The research leading to these results was supported by MICINN supporting the Ramón y Cajal grant for M.A. Prieto (RYC-2017-22891); by Xunta de Galicia for supporting the program EXCELENCIA-ED431F (1 December 2020), the post-doctoral grant of L. Cassani (ED481B2021/152), and the program Grupos de Referencia Competitiva (GRUPO AA1-GRC 2018) that supports the work of M. Barral-Martínez. The authors thank the program BENEFICIOS DO CONSUMO DAS ESPECIES TINTORERA-(CO-0019-2021) that supports the work of F. Chamorro. The research leading to these results was supported by the European Union through the "NextGenerationEU" program supporting the "Margarita Salas" grant awarded to P. Garcia-Perez. The authors are grateful to AlgaMar enterprise (www.algamar.com, accessed 30 December 2021) for the collaboration and algae material provision. The project SYSTEMIC Knowledge hub on Nutrition and Food Security has received funding from national research funding parties in Belgium (FWO), France (INRA), Germany (BLE), Italy (MIPAAF), Latvia (IZM), Norway (RCN), Portugal (FCT), and Spain (AEI) in a joint action of JPI HDHL, JPI-OCEANS and FACCE-JPI launched in 2019 under the ERA-NET ERA-HDHL (n 696295).

Conflicts of Interest: The authors declare no conflict of interest.

\section{References}

1. Kadam, S.U.; Álvarez, C.; Tiwari, B.K.; O’Donnell, C.P. Processing of seaweeds. In Seaweed Sustainability: Food and Non-Food Applications; Elsevier Inc.: Amsterdam, The Netherlands, 2015; pp. 61-78, ISBN 9780124199583.

2. Casoni, A.I.; Ramos, F.D.; Estrada, V.; Diaz, M.S. Sustainable and economic analysis of marine macroalgae based chemicals production-Process design and optimization. J. Clean. Prod. 2020, 276, 122792. [CrossRef] 
3. Cassani, L.; Gomez-Zavaglia, A.; Jimenez-Lopez, C.; Lourenço-Lopes, C.; Prieto, M.A.; Simal-Gandara, J. Seaweed-based natural ingredients: Stability of phlorotannins during extraction, storage, passage through the gastrointestinal tract and potential incorporation into functional foods. Food Res. Int. 2020, 137, 109676. [CrossRef]

4. $\quad$ Singh, S.; Verma, D.K.; Thakur, M.; Tripathy, S.; Patel, A.R.; Shah, N.; Utama, G.L.; Srivastav, P.P.; Benavente-Valdés, J.R.; Chávez-González, M.L.; et al. Supercritical fluid extraction (SCFE) as green extraction technology for high-value metabolites of algae, its potential trends in food and human health. Food Res. Int. 2021, 150, 110746. [CrossRef]

5. Fleurence, J.; Morançais, M.; Dumay, J. Seaweed Proteins, 2nd ed.; Elsevier Ltd.: Amsterdam, The Netherlands, 2018; ISBN 9780081007297

6. Quitral, V.; Sepúlveda, M.; Gamero-Vega, G.; Jiménez, P. Seaweeds in bakery and farinaceous foods: A mini-review. Int. J. Gastron. Food Sci. 2021, 1, 100403. [CrossRef]

7. Cassani, L.; Marcovich, N.E.; Gomez-Zavaglia, A. Seaweed bioactive compounds: Promising and safe inputs for the green synthesis of metal nanoparticles in the food industry. Crit. Rev. Food Sci. Nutr. 2021,1,1-24. [CrossRef]

8. Lourenço-Lopes, C.; Fraga-Corral, M.; Jimenez-Lopez, C.; Pereira, A.G.; Garcia-Oliveira, P.; Carpena, M.; Prieto, M.A.; Simal-Gandara, J. Metabolites from macroalgae and its applications in the cosmetic industry: A circular economy approach. Resources 2020, 9, 101. [CrossRef]

9. Cotas, J.; Leandro, A.; Monteiro, P.; Pacheco, D.; Figueirinha, A.; Gonçalves, A.M.M.; Jorge, G.; Pereira, L. Seaweed Phenolics: From Extraction to Applications. Mar. Drugs 2020, 18, 384. [CrossRef]

10. Wei, N.; Quarterman, J.; Jin, Y.S. Marine macroalgae: An untapped resource for producing fuels and chemicals. Trends Biotechnol. 2013, 31, 70-77. [CrossRef]

11. Kumar, S.; Roat, P.; Hada, S.; Chechani, B.; Kumari, N.; Ghodke, P.; Rawat, D.S. Catalytic Approach for Production of Hydrocarbon Rich Bio-Oil from a Red Seaweed Species. In Biotechnology for Biofuels: A Sustainable Green Energy Solution; Springer: Singapore, 2020; pp. 109-133.

12. Chen, H.; Zhou, D.; Luo, G.; Zhang, S.; Chen, J. Macroalgae for biofuels production: Progress and perspectives. Renew. Sustain. Energy Rev. 2015, 47, 427-437. [CrossRef]

13. Pourkarimi, S.; Hallajisani, A.; Alizadehdakhel, A.; Nouralishahi, A. Biofuel production through micro- and macroalgae pyrolysis - A review of pyrolysis methods and process parameters. J. Anal. Appl. Pyrolysis 2019, 142, 104599. [CrossRef]

14. Sánchez-Machado, D.I.; López-Cervantes, J.; López-Hernández, J.; Paseiro-Losada, P. Fatty acids, total lipid, protein and ash contents of processed edible seaweeds. Food Chem. 2004, 85, 439-444. [CrossRef]

15. Taboada, M.C.; Millán, R.; Miguez, M.I. Nutritional value of the marine algae wakame (Undaria pinnatifida) and nori (Porphyra purpurea) as food supplements. J. Appl. Phycol. 2013, 25, 1271-1276. [CrossRef]

16. Garcia-Vaquero, M.; Hayes, M. Red and green macroalgae for fish and animal feed and human functional food development. Food Rev. Int. 2016, 32, 15-45. [CrossRef]

17. Hentati, F.; Tounsi, L.; Djomdi, D.; Pierre, G.; Delattre, C.; Ursu, A.V.; Fendri, I.; Abdelkafi, S.; Michaud, P. Bioactive polysaccharides from seaweeds. Molecules 2020, 25, 3152. [CrossRef]

18. Rioux, L.E.; Turgeon, S.L. Seaweed Carbohydrates; Elsevier Inc.: Amsterdam, The Netherlands, 2015 ; ISBN 9780124199583.

19. Priyan Shanura Fernando, I.; Kim, K.N.; Kim, D.; Jeon, Y.J. Algal polysaccharides: Potential bioactive substances for cosmeceutical applications. Crit. Rev. Biotechnol. 2019, 39, 99-113. [CrossRef]

20. Otero, P.; Carpena, M.; Garcia-Oliveira, P.; Echave, J.; Soria-Lopez, A.; Garcia-Perez, P.; Fraga-Corral, M.; Cao, H.; Nie, S.; Xiao, J.; et al. Seaweed polysaccharides: Emerging extraction technologies, chemical modifications and bioactive properties. Crit. Rev. Food Sci. Nutr. 2021, 1, 1-29. [CrossRef]

21. Lopes, D.; Melo, T.; Meneses, J.; Abreu, M.H.; Pereira, R.; Domingues, P.; Lillebø, A.I.; Calado, R.; Rosário Domingues, M. A New Look for the Red Macroalga Palmaria palmata: A seafood with polar lipids rich in EPA and with antioxidant properties. Mar. Drugs 2019, 17, 533. [CrossRef]

22. Yaich, H.; Garna, H.; Besbes, S.; Paquot, M.; Blecker, C.; Attia, H. Chemical composition and functional properties of Ulva lactuca seaweed collected in Tunisia. Food Chem. 2011, 128, 895-901. [CrossRef]

23. Schmid, M.; Kraft, L.G.K.; van der Loos, L.M.; Kraft, G.T.; Virtue, P.; Nichols, P.D.; Hurd, C.L. Southern Australian seaweeds: A promising resource for omega-3 fatty acids. Food Chem. 2018, 265, 70-77. [CrossRef]

24. Mæhre, H.K.; Malde, M.K.; Eilertsen, K.E.; Elvevoll, E.O. Characterization of protein, lipid and mineral contents in common Norwegian seaweeds and evaluation of their potential as food and feed. J. Sci. Food Agric. 2014, 94, 3281-3290. [CrossRef]

25. Holdt, S.L.; Kraan, S. Bioactive compounds in seaweed: Functional food applications and legislation. J. Appl. Phycol. 2011, 23, 543-597. [CrossRef]

26. Fernandes, E.R.K.; Marangoni, C.; Souza, O.; Sellin, N. Thermochemical characterization of banana leaves as a potential energy source. Energy Convers. Manag. 2013, 75, 603-608. [CrossRef]

27. Cordero, T.; Marquez, F.; Rodriguez-Mirasol, J.; Rodriguez, J. Predicting heating values of lignocellulosics and carbonaceous materials from proximate analysis. Fuel 2001, 80, 1567-1571. [CrossRef]

28. Roslee, A.N.; Munajat, N.F. Comparative study on the pyrolysis behaviour and kinetics of two macroalgae biomass (Gracilaria changii and Gelidium pusillum) by thermogravimetric analysis. Proc. IOP Conf. Ser. Mater. Sci. Eng. 2017, 257, 012037. [CrossRef]

29. Ross, A.B.; Jones, J.M.; Kubacki, M.L.; Bridgeman, T. Classification of macroalgae as fuel and its thermochemical behaviour. Bioresour. Technol. 2008, 99, 6494-6504. [CrossRef] 
30. Kebelmann, K.; Hornung, A.; Karsten, U.; Griffiths, G. Thermo-chemical behaviour and chemical product formation from Polar seaweeds during intermediate pyrolysis. J. Anal. Appl. Pyrolysis 2013, 75, 603-608. [CrossRef]

31. Membere, E.; Sallis, P. Thermochemical characterization of brown seaweed, Laminaria digitata from UK shores. J. Anal. Appl. Pyrolysis 2018, 131, 42-51. [CrossRef]

32. Chan, P.T.; Matanjun, P.; Yasir, S.M.; Tan, T.S. Antioxidant activities and polyphenolics of various solvent extracts of red seaweed, Gracilaria changii. J. Appl. Phycol. 2015, 27, 2377-2386. [CrossRef]

33. Silva, A.; Rodrigues, C.; Garcia-Oliveira, P.; Lourenço-Lopes, C.; Silva, S.A.; Garcia-Perez, P.; Carvalho, A.P.; Domingues, V.F.; Barroso, M.F.; Delerue-Matos, C.; et al. Screening of bioactive properties in brown algae from the northwest iberian peninsula. Foods 2021, 10, 1915. [CrossRef]

34. Pérez-Jiménez, J.; Arranz, S.; Tabernero, M.; Díaz- Rubio, M.E.; Serrano, J.; Goñi, I.; Saura-Calixto, F. Updated methodology to determine antioxidant capacity in plant foods, oils and beverages: Extraction, measurement and expression of results. Food Res. Int. 2008, 41, 274-285. [CrossRef]

35. Cassani, L.; Gerbino, E.; del Rosario Moreira, M.; Gómez-Zavaglia, A. Influence of non-thermal processing and storage conditions on the release of health-related compounds after in vitro gastrointestinal digestion of fiber-enriched strawberry juices. J. Funct. Foods 2018, 40, 128-136. [CrossRef]

36. Rajauria, G. In-vitro antioxidant properties of lipophilic antioxidant compounds from 3 brown seaweed. Antioxidants 2019, 8, 596. [CrossRef]

37. Belda, M.; Sanchez, D.; Bover, E.; Prieto, B.; Padrón, C.; Cejalvo, D.; Lloris, J.M. Extraction of polyphenols in Himanthalia elongata and determination by high performance liquid chromatography with diode array detector prior to its potential use against oxidative stress. J. Chromatogr. B Anal. Technol. Biomed. Life Sci. 2016, 1033, 334-341. [CrossRef]

38. Osório, C.; Machado, S.; Peixoto, J.; Bessada, S.; Pimentel, F.B.; Alves, R.C.; Oliveira, M.B.P.P. Pigments content (Chlorophylls, fucoxanthin and phycobiliproteins) of different commercial dried algae. Separations 2020, 7, 33. [CrossRef]

39. Lourenço-Lopes, C.; Fraga-Corral, M.; Jimenez-Lopez, C.; Carpena, M.; Pereira, A.G.; Garcia-Oliveira, P.; Prieto, M.A.; Simal-Gandara, J. Biological action mechanisms of fucoxanthin extracted from algae for application in food and cosmetic industries. Trends Food Sci. Technol. 2021, 117, 163-181. [CrossRef]

40. Yalçın, S.; Karakaş, Ö.; Okudan, E.Ş.; Başkan, K.S.; Çekiç, S.D.; Apak, R. HPLC Detection and Antioxidant Capacity Determination of Brown, Red and Green Algal Pigments in Seaweed Extracts. J. Chromatogr. Sci. 2021, 59, 325-337. [CrossRef]

41. Chakraborty, K.; Maneesh, A.; Makkar, F. Antioxidant Activity of Brown Seaweeds. J. Aquat. Food Prod. Technol. 2017, 26, 406-419. [CrossRef]

42. García-Pérez, P.; Losada-Barreiro, S.; Bravo-Díaz, C.; Gallego, P.P. Exploring the use of bryophyllum as natural source of bioactive compounds with antioxidant activity to prevent lipid oxidation of fish oil-in-water emulsions. Plants 2020, 9, 1012. [CrossRef]

43. Lage, M.Á.P.; García, M.A.M.; Álvarez, J.A.V.; Anders, Y.; Curran, T.P. A new microplate procedure for simultaneous assessment of lipophilic and hydrophilic antioxidants and pro-oxidants, using crocin and $\beta$-carotene bleaching methods in a single combined assay: Tea extracts as a case study. Food Res. Int. 2013, 53, 836-846. [CrossRef]

44. García-Pérez, P.; Ayuso, M.; Lozano-Milo, E.; Pereira, C.; Dias, M.I.; Ivanov, M.; Calhelha, R.C.; Soković, M.; Ferreira, I.C.F.R.; Barros, L.; et al. Phenolic profiling and in vitro bioactivities of three medicinal Bryophyllum plants. Ind. Crops Prod. 2021, 162, 113241. [CrossRef]

45. Taboada, C.; Millan, R.; Miguez, I. Evaluation of marine algae Undaria pinnatifida and Porphyra purpurea as a food supplement: Composition, nutritional value and effect of intake on intestinal, hepatic and renal enzyme activities in rats. J. Sci. Food Agric. 2013, 93, 1863-1868. [CrossRef]

46. Lee, C.W.; Ahn, Y.T.; Zhao, R.; Kim, Y.S.; Park, S.M.; Jung, D.H.; Kim, J.K.; Kim, H.W.; Kim, S.C.; An, W.G. Inhibitory effects of porphyra tenera extract on oxidation and inflammatory responses. Evid.-Based Complement. Altern. Med. 2021, 1, 1-10. [CrossRef]

47. Sakthivel, R.; Devi, K.P. Antioxidant, anti-inflammatory and anticancer potential of natural bioactive compounds from seaweeds Stud. Nat. Prod. Chem. 2019, 63, 113-160.

48. Millos, J.; Costas-Rodríguez, M.; Lavilla, I.; Bendicho, C. Multiple small volume microwave-assisted digestions using conventional equipment for multielemental analysis of human breast biopsies by inductively coupled plasma optical emission spectrometry. Talanta 2009, 77, 1490-1496. [CrossRef]

49. Millos, J.; Costas-Rodríguez, M.; Lavilla, I.; Bendicho, C. Multielemental determination in breast cancerous and non-cancerous biopsies by inductively coupled plasma-mass spectrometry following small volume microwave-assisted digestion. Anal. Chim. Acta 2008, 622, 77-84. [CrossRef]

50. Cassani, L.; Tomadoni, B.; Ponce, A.; Agüero, M.V.; Moreira, M.R. Combined Use of Ultrasound and Vanillin to Improve Quality Parameters and Safety of Strawberry Juice Enriched with Prebiotic Fibers. Food Bioprocess Technol. 2017, 10, 1454-1465. [CrossRef]

51. Scott, K.J. Detection and measurement of carotenoids by UV/VIS spectrophotometry. Curr. Protoc. Food Anal. Chem. 2005, 81-90. [CrossRef]

52. Olszowy, M.; Dawidowicz, A.L. Essential oils as antioxidants: Their evaluation by DPPH, ABTS, FRAP, CUPRAC, and $\beta$-carotene bleaching methods. Mon. Chem. 2016, 147, 2083-2091. [CrossRef] 
53. Prieto, M.A.; Rodríguez-Amado, I.; Vázquez, J.A.; Murado, M.A. $\beta$-Carotene assay revisited. Application to characterize and quantify antioxidant and prooxidant activities in a microplate. J. Agric. Food Chem. 2012, 60, 8983-8993. [CrossRef]

54. Prieto, M.A.; Vázquez, J.A.; Murado, M.A. Crocin bleaching antioxidant assay revisited: Application to microplate to analyse antioxidant and pro-oxidant activities. Food Chem. 2015, 1, 299-310. [CrossRef] [PubMed] 